CALCINATION OF FLUORINEL-SODIUM WASTE BLENDS

USING SUGAR AS A FEED ADDITIVE (FORMERLY WINCO-11879)

B.J. Newby T.D. Thomson B.H. OBien 


\section{B.J. Newby}

T.D. Thomson

B.H. OBrien

June 1992

W Westinghouse Idaho

PREPARED FOR THE

DEPARTMENT OF ENERGY

IDAHO OPERATIONS OFFICE

UNDER CONTRACT DE-AC07-84ID12435 
WINCO-11879

\title{
CALCINATION OF FLUORINEL-SODIUM WASTE BLENDS USING SUGAR AS A FEED ADDITIVE
}

B. J. Newby

T. D. Thomson

B. H. O'Brien

June 1992

\section{Westinghouse Idaho Wuclear Company, Inc.}

\author{
PREPARED FOR THE \\ DEPARTMENT OF ENERGY \\ IDAHO OPERATIONS OFFICE \\ UNDER CONTRACT DE-AC07-84ID12.435
}


Methods were studied for using sugar as a feed additive for converting the sodium-bearing wastes stored at the Idaho Chemical Processing $\mathrm{Pl}$ ant into granular, free flowing solids by fluidized-bed calcination at $500^{\circ} \mathrm{C}$. All methods studied blended sodium-bearing wastes with Fluorinel wastes but differed in the types of sugar (sucrose or dextrose) that were added to the blend. The most promising sugar additive was determined to be sucrose, since it is converted more completely to inorganic carbon than is dextrose. The effect of the feed aluminum-to-alkali metal mole ratio on calcination of these blends with sugar was also investigated. Increasing the aluminum-to-alkali metal ratio from 0.6 to 1.0 decreased the calcine product-to-fines ratio from 3.0 to 1.0 and the attrition index from 80 to $15 \%$. Further increasing the ratio to 1.25 had no effect. 
Summary

One of the major wastes being generated and stored at the Idaho Chemical Processing Plant (ICPP) is sodium-bearing ( $\mathrm{Na}$ ) waste. The waste is difficult to calcine; the sodium nitrate present causes fluidized-bed agglomeration during calcination, and the chloride present can cause excessive corrosion (>51 micrometers/mo or $>2 \mathrm{mils} / \mathrm{mo}$ ) of off-gas scrubbing equipment when volatilized from the calciner vessel and collected by the off-gas scrubbing equipment.

Tests were carried out in the enclosed $10-\mathrm{cm}$ diameter Calciner Pilot-Plant attempting to calcine Fluorinel - Na waste blends, having up to 7.5 mole \% sodium plus potassium in the calcined solids, using sugar as a feed additive. Studies in the enclosed $10-\mathrm{cm}$ diameter calciner indicated that the presence of sugar (sucrose or dextrose) in simulated Fluorinel - Na waste blends containing alkali metals (sodium plus potassium) effectively destroys nitrates in the blend during calcination. The studies also showed that, because of the destruction of nitrates, the presence of sugar: a) allows alkali metals present to form compounds stable at calcination temperatures, b) allows the size of the product to be readily controlled using the feed nozzle air-to-feed ratio (NAR), and c) results in high chloride retention in calcined solids.

The tests in this report tried to determine a) which sugar (sucrose or dextrose) was the most effective for calcining Fluorinel - Na waste blends, and b) the effect of the feed aluminum-to-alkali metal mole ratio on the calcination of these blends. The sucrose and dextrose added to the blends were equally effective at destroying nitrates. An average of $45 \%$ of the nitrates in the feed for the runs was destroyed during the sugar reactions. Sucrose was determined to be the most promising sugar additive since it was converted more completely to inorganic carbon than was dextrose. When sucrose was used as an additive the wt\% of total carbon fed to the calciner that was found in calciner streams as organic (unburned and/or not converted to inorganic carbon) carbon averaged 3 wt\%; whereas, when dextrose was used as an additive the average was 34 wt\% organic carbon. If dextrose were used in the in the NWCF, the 
larger amount of organic carbon would probably plug filters and silica gel beds.

Retrieval tests were performed on homogenous mixtures of product and fines collected following each run. Each retrieval test consisted of attempting (several times) to retrieve a mixture of product and fines (that has been subjected to $650^{\circ} \mathrm{C}$ and a pressure of $8.7 \mathrm{psig}$ for three days in a sealed can) from a can using a vacuum nozzle with vibrator assistance. During retrieval tests a loading rate of $1.5 \mathrm{~kg}$ of calcined solids per $\mathrm{kg}$ of vacuum air is considered satisfactory. Both increasing the feed alkali metal concentration and using sugar as a feed additive seemed to have an adverse effect on calcine retrieval rates. The average retrieval rates for runs FINaS-1, -2, -3, -5 , and -6 were $1.7,3.3,1.1$, 1.4 , and $2.6 \mathrm{~kg}$ calcine per $\mathrm{kg}$ air, respectively. Cadmium metal crystals plated-out on the interior surface of the can's lid while the mixture from run FINaS-4 was being subjected to heat. This prevented the system that subjects the calcined solids to pressure from working. Heating run FINaS- 6 solids rusted parts of the stainless steel retrieval equipment that would be in contact with any gases evolved from the calcine and flaked the inside of the retrieval vessel.

The runs also investigated feed aluminum-to-alkali metal ( $\mathrm{Al} / \mathrm{Na}+\mathrm{K})$ mole ratios of $0.6,1.0$ and 1.25 . Increasing the feed $A 1 / \mathrm{Na}+\mathrm{K}$ mole ratio from 0.6 to 1.0 decreased the calcine product-to-fines ratio from 3.0 to 1.0 , the product production rate from 250 to $-175 \mathrm{~g} / \mathrm{h}$, and the attrition index from 80 to $-15 \%$. Whereas, increasing the feed $A l / \mathrm{Na}+\mathrm{K}$ mole ratio from 1.0 to 1.25 had little or no effect on the calcine product-to-fines ratio, product production rate, and attrition indices. Increasing the feed $\mathrm{Al} / \mathrm{Na}+\mathrm{K}$ mole ration from 0.6 to 1.25 had little or no effect on the behavior of chloride, fluoride, carbon, or cadmium during calcination. 
ABSTRACT PAGE

SUMMARY ............................ . .

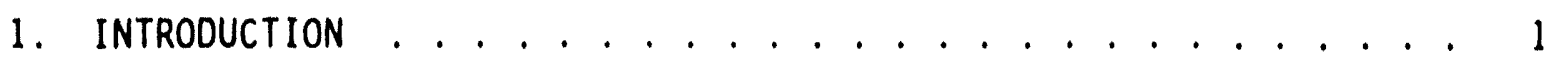

2. EXPERIMENTAL EQUIPMENT AND PROCEDURES . . . . . . . . . . . 5

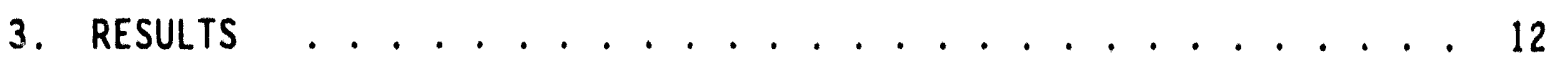

3.1 Calciner Operations . . . . . . . . . . . . . . . 12

3.2 Characteristics of Fluidized-Bed and Solids Produced . . 13

3.3 Behavior of Volatiles . . . . . . . . . . . . . . . 20

3.4 Miscellaneous Calcination Chemistry . . . . . . . . . . . . 24

4. CONCLUSIONS AND RECOMMENDATIONS . . . . . . . . . . . . 27

4.1 Conclusions . . . . . . . . . . . . . . . . . . 27

4.2 Recommendations . . . . . . . . . . . . . . . . 28

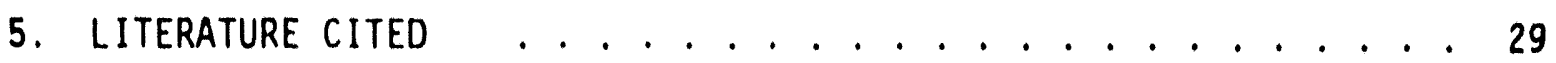

APPENDIX A . . . . . . . . . . . . . . . . . . . A-1

APPENDIX B ........................ B-1

APPENDIXC . . . . . . . . . . . . . . . . . . . . . C-1

APPENDIX D . . . . . . . . . . . . . . . . . . . . . . D-1

FIGURES

1. Enclosed 10-cm Diameter Calciner . . . . . . . . . . . 6

2. Variation of MMPD with Waste NAR During Runs FINaS-1 and -2 . . 14

3. Variation of MMPD with Waste NAR During Runs FINaS-3 and -4 . 15

4. Variation of MMPD with Waste NAR During Runs FINaS-5 and -6 . . 16 
TABLES

1. Parameters Adjusted During Enclosed $10-\mathrm{cm} \mathrm{Calciner}$ Runs Using Sugar . . . . . . . . . . . . . . . . . . 2

2. Compositions of Fluorinel and Sodium Wastes Used for Test Blends 3

3. Feed Nitrate Destruction During Sugar Treatment . . . . . . . . 8

4. Compositions of Wastes And Blends Prior to Calcium Nitrate and Sugar Treatment . . . . . . . . . . . . 9

5. Compositions of Blends After Calcium Nitrate and Sugar Treatment ....................... . 11

6. Average Characteristics of Fluidized-Bed and Solids Produces During Calcination of Fluorinel-Na Waste-Sugar Blends . . . . 17

7. Pneumatic Retrieval Rates Using a Vibrator-Assisted Vacuum Nozzle . . . . . . . . . . . . . . . . . 20

8. Chloride Behavior in Calciner Off-Gas During Runs Finas-1, $-2,-3,-4,-5$, and -6 . . . . . . . . . . . . 22

9. Carbon Behavior During Runs FINaS-1, -2, -3, -4, -5, and -6 . . 23

10. Carbon Monoxide in Off-Gas During $10 \mathrm{~cm} \mathrm{Calciner} \mathrm{Run} \mathrm{FINaS-4} \mathrm{.} 25$

A-1 Operating Conditions for Runs FINaS-1 and -2 . . . . . . . A-2

A-2 Characteristics of Fluidized-Bed and Solids Produced During Runs FINaS-1 and -2 ................ A-3

B-1 Operating Conditions for Runs FINaS-3 and -4 . . . . . . . . B-2

B-2 Characteristics of Fluidized-Bed and Solids Produced During Runs FINaS-3 and -4 ................. B-3

C-1 Operating Conditions for Runs FINaS-5 and -6 . . . . . . . C-2

C-2 Operating Conditions for Runs FINaS-5 and -6 (continued) ... C-3

C- 3 Characteristics of Fluidized-Bed and Solids Produced During Runs FINaS-5 and -6 .................. . C-4

C-4 Characteristics of Fluidized-Bed and Solids Produced During Runs FINaS-5 and -6 (continued) .. . . . . . . . . C-5

D-1 $20 x$ Magnification Photographs of Final Bed Calcine Particles 


\section{INTRODUCTION}

Sodium-bearing $(\mathrm{Na})$ waste now occuples six of the ten 300,000 gallon storage tanks in the Idaho Chemical Processing Plant (ICPP) tank farm. Though effective for disposing of the $\mathrm{Na}$ wastes, calcination of $\mathrm{Na}$ wastes as a zirconium-fluoride-Na waste blend has not kept up with the generation of $\mathrm{Na}$ wastes. Therefore, necessary development is underway to modify the $\mathrm{Na}-\mathrm{Fluorinel}$ waste blend chemistry such that blends containing more $\mathrm{Na}$ waste can be calcined.

Enclosed 10-cm diameter Calciner Pilot-Plant studies have shown that the presence of sucrose or dextrose (sugars) in simulated $\mathrm{Na}$-Fluorinel waste blends containing alkali metals (sodium plus potassium) effectively destroys nitrates in the blend during calcination.' The destruction of nitrates is desirable since it reduces calcine particle agglomeration to form stable sodium compounds. The same studies have shown that, because of this nitrate destruction, the presence of sugar: a) allows alkali metals present to form compounds stable at calcination temperatures, b) allows the size of the product to be readily controlled using the feed nozzle air to feed ratio (NAR), and $c$ ) results in high chloride retention in calcined solids. This may allow the New Waste Calcining Facility (NWCF) to calcine a blend of less than 5:1 volume fluorinel to $\mathrm{Na}$ waste, which would produce calcine containing greater then 5.3 mole\% alkali metal (a technical specification limit), without product particle size control problems. The $\mathrm{Na}$ waste inventory could then be depleted at a faster rate. Such calcine would also have to have an acceptably high caking temperature to be retrievable from the storage bins.

The greatest disadvantage of using sugar when calcining blends of $\mathrm{Na}$ waste and aluminum nitrate in a $10 \mathrm{~cm}$ calciner was that incomplete combustion of the sugar produced large amounts of unburned carbon which could plug up silica gel beds and filters. ${ }^{2}$ Batch calcination showed that roughly $34.5 \mathrm{~g}$ of sugar per mole of nitrate in the feed blend would effectively destroy nitrates in Fluorinel-Na waste blends regardless of whether the sugar had 5, 6, or 12 carbons, the sugar was an aldehyde or ketone, or the sugar was a reducing or nonreducing sugar. Two of the 
cheaper sugars (sucrose and dextrose) were selected for further $10-\mathrm{cm}$ fluidized-bed calciner studies.

A series of six pllot-plant calciner runs were made in the Enclosed $10 \mathrm{~cm}$ Calciner Pilot-Plant to test the use of sugar as a feed additive to reduce alkali metal nitrate formation when Fluorinel/Sodium Blends were calcined. The type of sugar (sucrose or dextrose), theoretical alkalt metal content of the calcined solids, and aluminum-to-alkali-metal mole ratio were varied during the test series to assess their effects on calcination (Table 1). The compositions of simulated fluorinel and Sodium Waste used in the tests are given in Table 2.

Tabie 1. Parameters Adjusted During Enclosed 10-cm Calciner Tests Using Sugar As A Feed Additive with FluorinelSodium Blends.

\begin{tabular}{|c|c|c|c|c||}
\hline Run No. & $\begin{array}{c}\text { Type of } \\
\text { Sugar }\end{array}$ & $\begin{array}{c}\text { Alkall Metal (Sodium } \\
\text { plus Potassium) Content } \\
\text { of Calcine (Mole } x \text { ) }\end{array}$ & $\begin{array}{c}\text { Aluminum-to-Alkall } \\
\text { Matal Mole Ratio }\end{array}$ & $\begin{array}{c}\text { Fluorinel-to-Sodium } \\
\text { Volume Ratio }\end{array}$ \\
\hline 1 & Sucrose & 5.3 & 1.0 & 4.5 \\
\hline 2 & Dextrose & 5.3 & 1.0 & 4.5 \\
\hline 3 & Sucrose & 7.5 & 1.0 & 2.8 \\
\hline 4 & Dextrose & 7.5 & 1.0 & 2.8 \\
\hline 5 & Sucrose & 7.5 & 0.60 & 3.15 \\
\hline 6 & Sucrose & 7.5 & 1.25 & 2.63 \\
\hline Note: & $\begin{array}{l}\text { All runs used a calcium-to-fluoride mole ratio of } 0.7 \text { and } 34.59 \text { of sugar adder per } \\
\text { mole of feed nitrate. }\end{array}$ \\
\hline
\end{tabular}

Runs FINaS-1 and -2 were the first in the test series and were designed to evaluate the effectiveness of sugar as a feed additive for calcining blends of Fluorinel and Sodium wastes at an alkali metal content which is calcinable without sugar $(5.3$ mole $\%)$. Both runs used an aluminum-to-alkali metal mole ratio of 1.0, a calcium-to-fluoride mole ratio of 0.7 , and produced calcine containing 5.3 mole\% alkali metal.

The purpose of Runs FINaS-3 and -4 was to test the calcinability of feed which produced calcine containing 7.5 mole \% alkali metal, an alkali metal content higher than that calcinable for Fluorinel/Na blends without sugar. Being able to calcine and retrieve solids from blends producing calcine containing 7.5 mole\% alkali metal rather than containing 5.3 
mole\% would reduce the Fluorinel-to-Na waste volume ratio in Fluorinel-Na waste blends by about 38 vol \%. This would increase the Na waste calcination rate by a corresponding percentage. Both runs used an aluminum-to-alkalf metal mole ration of 1.0 and a calcium-to-fluoride mole ratio of 0.7 .

The purpose of Runs FINaS-5 and -6 was to test how calcination characteristics of Fluorinel-Na waste blends containing sucrose are affected by changes of the aluminum-to-alkali metal mole ratio in the feed. The feed for Run FINaS-5 was a blend of 3.15 vol Fluorinel to 1.0 vol $\mathrm{Na}$ waste containing an aluminum-to-alkali metal mole ratio of 0.60 . The feed for Run FINaS-6 was a blend of 2.63 vol fluorinel to 1.0 vol $\mathrm{Na}$ waste containing an aluminum-to-alkali metal mole ratio of 1.25 . Both runs used feed that contained a calcium-to-fluoride mole ratio of 0.7 and produced calcine containing 7.5 mole \% alkali metal.

One disadvantage in using sugar when calcining blends of Fluorinel and $\mathrm{Na}$ wastes is that more calcine fines are produced than desired because the calcine product is soft. ${ }^{2}$ Runs FINaS-1, -2, -3 , and -4 calcined blends of Fluorinel and $\mathrm{Na}$ wastes with sugar using feeds that

Table 2. Compositions of Fluorinel and Sodium Wastes Used for Sugar Tests

\begin{tabular}{|c|c|c|}
\hline Constituent & Fluorinel Waste & Sodium Waste \\
\hline$H^{+}\left(N_{-}^{a}\right)$ & 1.91 & 1.6 \\
\hline$A 1(M)$ & 0.233 & 0.7 \\
\hline $2 r(M)$ & 0.431 & \\
\hline$B(M)$ & 0.22 & \\
\hline$N_{a}(M)$ & & 2.1 \\
\hline$K(M)$ & & 0.3 \\
\hline$C d(M)$ & 0.14 & \\
\hline $\mathrm{NH}_{4}^{+}(M)$ & 0.052 & \\
\hline$F(M)$ & 3.03 & 6.0 \\
\hline $\mathrm{NO}_{3}(M)$ & 2.26 & 0.07 \\
\hline $\mathrm{SO}_{4}(M)$ & 0.080 & 1,775 \\
\hline $\mathrm{Cl}(\mu \mathrm{g} / \mathrm{ml})$ & & \\
\hline
\end{tabular}


contained an aluminum-to-alkali metal mole ratio of 1.0 . It was thoight that feeds with aluminum-to-alkall metal mole ratios of 0.60 or 1.25 might enhance production of alkall metal-alumina compounds during calcination that would reduce fines production. Increasing aluminum nitrate concentrations of a waste feed prior to calcination will most likely increase the hardness of the calcine produced. However, not having to add cold aluminum nitrate to the feed to obtain an aluminum-to-alkall metal nole ratlo of 1.0 would: 1) decrease the amount. of sugar that needed to be added to the feed (which in turn would cause the feed to produce less unburned sugar when calcined), and 2) increase the calcination volume reduction factor. 


\section{EXPERIMENTAL EQUIPMENT AND PROCEDURES}

A schematic diagram of the enclosed $10-\mathrm{cm}$-diameter Calciner Pllot-Plant used in the runs described in this report is shown in Figure 1. The feed was sprayed into the calciner under the surface of a fluidized-bed of particles and removed from the calciner as particles (product) and fines.

The calciner's fluidized-bed was heated by in -bed combustion of kerosene. A propane torch was used to raise the temperature inside the calciner above the autoignition temperature of a kerosene-oxygen mixture in the bed $\left(340^{\circ} \mathrm{C}\right)$. The calcination temperature was $500^{\circ} \mathrm{C}$. The feed nozzle used during every run was a Spraying Systems Co. 40100 liquid, 120 air. The fuel nozzle used for Runs FINaS-1, -2, $-3,-4$, and -6 was a Spraying System Co. 2050 liquid, 67-6-20-70 air; whereas, the fuel nozzle used for Run FINaS-5 was a Spraying Systems Co. 1650 Liquid, 67-6-20-70 air. The size of the calcine particles was controlled by varying the feed nozzle air ratio (NAR).

Off-gas leaving the enclosed 10-cm-diameter Calciner Pilot-Plant. passed through (in the order named): a primary cyclone to remove fines, a venturi scrubber (containing nitric acid) for further fines removal, a secondary cyclone, and finally through two water cooled condensers. About 3.0 vol \% ( $4 \mathrm{sLpm})$ of the total off-gas was pulled through a caustic scrubber (to analytically determine chloride, carbon, cadmium, and fluoride volatility) from a point located between the secondary cyclone and the primary condenser.

If the temperature of the acid solution in the off-gas scrub tank was kept at $-70^{\circ} \mathrm{C}$ (the off-gas acid scrub solution of the NWCF is kept at $-70^{\circ} \mathrm{C}$ ), the scrub did not foam due to the scrubbing of unburned sugar (as the acid was depleted) within the 8 hour operating period (initial scrub acid concentration was $4.0 \mathrm{M}$ ). It is convenient to operate the enclosed 10-cm Calciner Pilot-Plant with the acid scrub tank at $-30^{\circ} \mathrm{C}$, but at this temperature $4 \mathrm{M}$ acid scrub foams in less than 4 hours when sugar is used as an additive. If allowed to foam too vigorously for too long, the scrub will solidify. To prevent foaming in Runs FlNaS-1, -2, -3, -4, -5, 


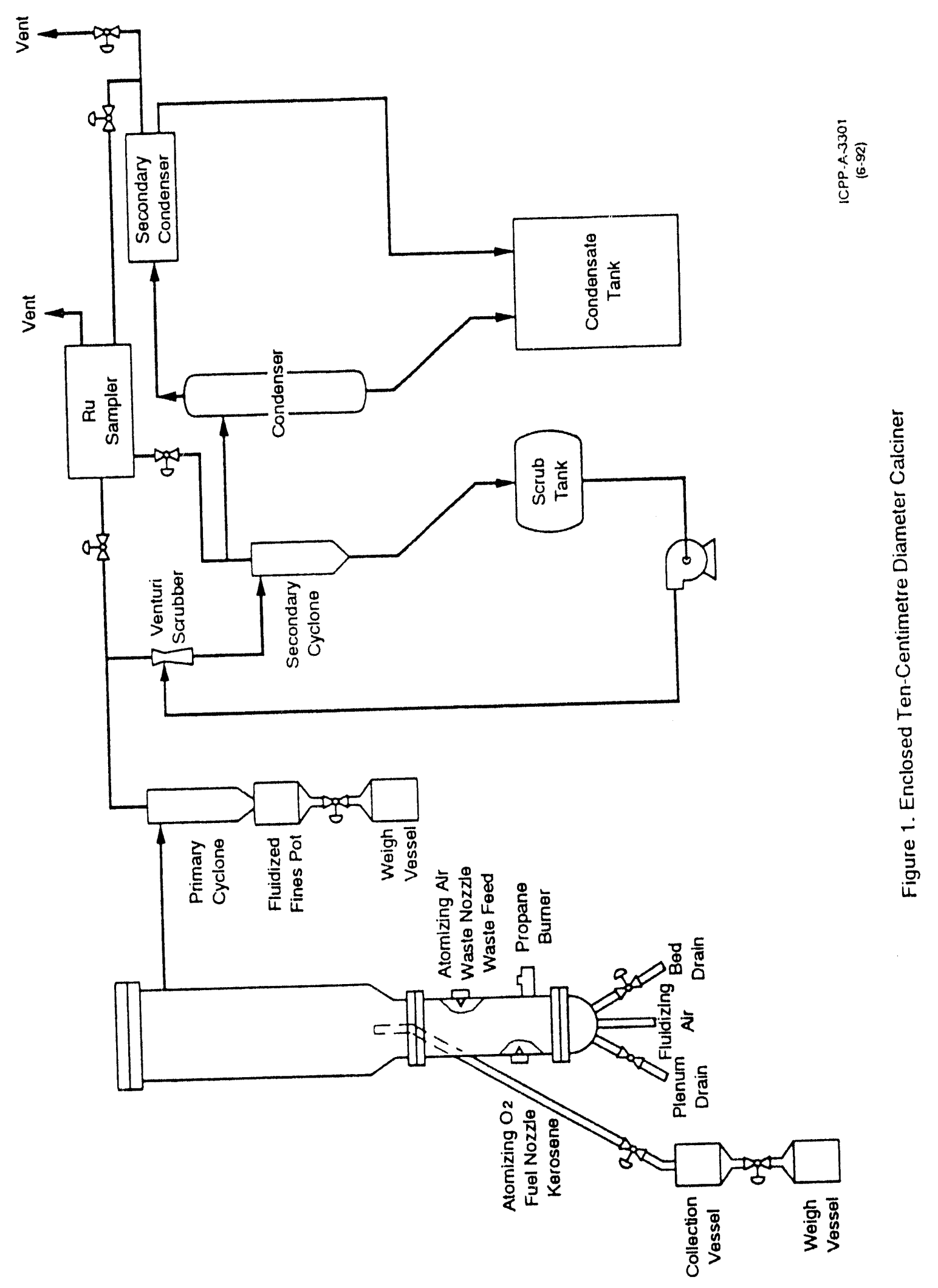


and -6 , the initial scrub solution in the venturi scrubber was $13 \underline{M}$ nitric acid; whenever the scrub foamed, the solution was removed from the scrubber system and replaced with new 13 M nitric acid. Acid scrub solution generated during a run was put in a carboy and a homogeneous sample was taken at the end of the run. Solution from the acid scrub system was not recycled to the calciner feed.

The caustic scrubber was operated, usually for 8 hour periods, at various times throughout the runs. One liter of $6 \underline{M}$ sodium hydroxide was added to the scrubber at the beginning of each operating period, and samples of caustic scrub were taken from the scrubber at the end of each operating period.

The feed containing calcium nitrate was sampled prior to being fed to the calciner. Samples of product and fines were taken every 8 hours.

In preparing feed for the runs, sugar was added slowly over a period of 30 minutes to a solution containing calcium nitrate at $80^{\circ} \mathrm{C}$. The reaction releasing $\mathrm{NO}_{x}$ typically occurred after a 1 to 2 hour induction period. The temperature of the feed was kept below $90^{\circ} \mathrm{C}$ using a cooling coil. Adding water to keep the volume constant, the feed was kept between 80 and $90^{\circ} \mathrm{C}$ for 2 hours, to make certain any reaction taking place between the sugar and the nitrates was completed and as much excess sugar as possible was destroyed. An average of $45 \%$ of the nitrates in the fuel for the runs was destroyed during the sugar reactions. Nitrate destruction for each feed is given in Table 3 .

The composition of the fluorinel and $\mathrm{Na}$ wastes used in runs $\mathrm{FiNaS-1}$, $-2,-3,-4,-5$, and -6 are given in Table 4 . The composition of these wastes correspond to those of future wastes predicted by P.A. Andersun ${ }^{3}$ and R.I. Donovan. ${ }^{4}$ Table 4 also gives the theoretical compositions of blends of 4.5 (Runs FINaS-1 and -2), 2.8 (Runs FINaS-3 and -4 ), 3.15 (Run FINaS-5), and 2.63 (Run FINaS-6) vol Fluorinel waste to 1.0 vol Na waste prior to treatment with calcium nitrate and sugar. The composition before calcium nitrate addition and sugar treatment is a theoretical composition, while the composition after calcium nitrate addition and 
Table 3. Feed Nitrate Destruction During Sugar Treatment

\begin{tabular}{|c|c|c|c|}
\hline Run FINaS- & $\begin{array}{c}\text { Feed } \mathrm{NO}_{3} \text { Prior To } \\
\text { Sugar Reaction } \\
\text { (M) }\end{array}$ & $\begin{array}{l}\text { Feed } \mathrm{NO}_{3} \text { After } \\
\text { Sugar Reaction } \\
\text { (M) }\end{array}$ & $\begin{array}{c}\text { Nitrate } \\
\text { Destroyed (\%) } \\
\end{array}$ \\
\hline 1 & 5.71 & 2.67 & $53 \%$ \\
\hline 2 & 5.71 & 2.98 & $48 \%$ \\
\hline 3 & 6.38 & 3.72 & $42 \%$ \\
\hline 4 & 6.38 & 3.56 & $44 \%$ \\
\hline 5 & 5.25 & 3.52 & $33 \%$ \\
\hline 6 & 6.41 & 3.27 & $49 \%$ \\
\hline & & Average & $45 \pm 7$ \\
\hline
\end{tabular}


Table 4. Theoretical Compositions of Wastes and Blends of Fluorinel and Sodium Wastes Prior to Calcium Nitrate and Sugar Treatment

\begin{tabular}{|c|c|c|c|c|c|c|}
\hline Const ituent & $\begin{array}{c}\text { Fluor inel } \\
\text { Waste }\end{array}$ & $\begin{array}{l}\text { Sodium } \\
\text { Waste }\end{array}$ & $\begin{array}{c}4.5: 1 \\
\text { Volume } \\
\text { Rat io } 8 \text { lend } \\
\text { (Runs } \\
\text { FINaS-1 and } \\
-2 \text { ) }\end{array}$ & $\begin{array}{c}2.8: 1 \\
\text { Volume } \\
\text { Rat io Blend } \\
\text { (Runs } \\
\text { FiNaS }-3 \text { and } \\
-4 \text { ) }\end{array}$ & $\begin{array}{c}3.15: 1 \\
\text { Volume Rat to } \\
\text { Blend (Run } \\
\text { FiNaS-5) }\end{array}$ & $\begin{array}{c}2.63: 1 \\
\text { Volume } \\
\text { Ratio } \\
\text { Blend (Run } \\
\text { FiNaS-6) } \\
\end{array}$ \\
\hline$H^{+}\left(N_{-}^{*}\right)$ & 1.91 & 1.6 & 1.85 & 1.83 & 1.84 & 1.82 \\
\hline$A 1(M)$ & 0.233 & 0.7 & 0.44 & 0.632 & 0.345 & 0.826 \\
\hline $2 r(M)$ & 0.431 & & 0.35 & 0.32 & 0.327 & 0.312 \\
\hline$B(M)$ & 0.22 & & 0.18 & 0.16 & 0.167 & 0.159 \\
\hline $\mathrm{Na}(\mathrm{M})$ & & 2.1 & 0.38 & 0.55 & 0.506 & 0.578 \\
\hline$K(M)$ & & 0.3 & 0.055 & 0.079 & 0.072 & 0.083 \\
\hline $\operatorname{cd}(M)$ & 0.14 & & 0.11 & 0.10 & 0.106 & 0.101 \\
\hline $\mathrm{HN}_{4}{ }^{+}(\underline{M})$ & 0.052 & & 0.043 & 0.038 & 0.040 & 0.038 \\
\hline$F(M)$ & 3.03 & & 2.48 & 2.23 & 2.30 & 2.20 \\
\hline $\mathrm{NO}_{3}(\mathrm{M})$ & 2.26 & 6.0 & 2.94 & 3.24 & 3.16 & 3.29 \\
\hline $\mathrm{SO}_{4}(\underline{M})$ & 0.080 & $\begin{array}{l}0.0 \\
7 \\
\end{array}$ & 0.078 & 0.077 & 0.078 & 0.077 \\
\hline Cl $(\mu \mathrm{g} / \mathrm{m}))$ & & 1.775 & $500^{\circ}$ & $500^{\circ}$ & $500^{\circ}$ & $500^{\circ}$ \\
\hline
\end{tabular}


sugar treatment is based on analyses of the calciner feeds. The composition of the feeds after calcium nitrate addition and sugar treatment are given in Table 5.

A sample from the acid scrub solution in each carboy, all caustic scrub samples, and solid samples taken at arbitrary intervals throughout the runs were analyzed for those constituents that would determine the cadmium, carbon, chloricie, and fluoride behavior during the runs. Acid scrub was also analyzed for those constituents that would show if fluoride corrosion to materials of construction in the NWCF acid scrub system would be excessive. Some product and fines were analyzed for their nitrate content and were also examined by $x$-ray diffraction and emission spectroscopy.

The following fluidized-bed characteristics were determined: a) the mass mean particle diameter (MMPD) and bulk density for the product collected every 8 hours; b) the attrition index (a measure of particle hardness), MMPD, weight, and bulk density for the starting and final calcine beds; c) the attrition index for product taken during the middle part of the run; d) bulk densities of fines collected every 8 hours; and e) weights of product and fines removed from the calcine bed. In addition, a photo was taken of particles of the final bed magnified twenty times to determine the appearance of the particle's surfaces. The bed and inside of the calciner were examined after each run. 
Table 5. Compositions of Blends After Calcium Nitrate And Sugar Treatment

\begin{tabular}{|c|c|c|c|c|c|c|}
\hline Const ituent & $\begin{array}{c}\text { Run } \\
\text { FINaS-1 } \\
\text { Feed }\end{array}$ & $\begin{array}{l}\text { Run } \\
\text { FINaS - } 2 \\
\text { Feed }\end{array}$ & $\begin{array}{c}\text { Run } \\
\text { FINaS-3 } \\
\text { Feed }\end{array}$ & $\begin{array}{c}\text { Run } \\
\text { FiNaS - } 4 \\
\text { Feed }\end{array}$ & $\begin{array}{c}\text { Run } \\
\text { FINaS-5 } \\
\text { Feed }\end{array}$ & $\begin{array}{c}\text { Run } \\
\text { F INaS-6 } \\
\text { Feed }\end{array}$ \\
\hline $\mathrm{H}^{+}\left(\mathrm{N}_{-}^{*}\right)$ & 0.84 & 0.98 & 1.18 & 1.25 & 0.96 & 0.70 \\
\hline$A)(M)$ & 0.38 & 0.38 & 0.62 & 0.54 & 0.32 & 0.75 \\
\hline $\operatorname{lr}(M)$ & 0.24 & 0.26 & 0.24 & 0.16 & 0.15 & 0.14 \\
\hline$B(M)$ & 0.13 & 0.11 & 0.18 & 0.11 & 0.13 & 0.14 \\
\hline $\mathrm{Na}(\mathrm{M})$ & 0.28 & 0.28 & 0.48 & 0.44 & 0.52 & 0.70 \\
\hline$K(M)$ & 0.041 & 0.042 & 0.070 & 0.068 & 0.061 & 0.11 \\
\hline $\operatorname{cd}(M)$ & 0.078 & 0.078 & 0.081 & 0.079 & 0.099 & 0.10 \\
\hline $\mathrm{Ca}(M)$ & 1.30 & 1.28 & 1.24 & 1.10 & 1.15 & 1.18 \\
\hline$F(M)$ & 1.79 & 1.93 & 1.59 & 1.46 & 1.56 & 1.72 \\
\hline $\mathrm{NO}_{3}(\mathrm{M})$ & 2.67 & 2.98 & 3.72 & 3.56 & 3.52 & 3.27 \\
\hline $\mathrm{SO}_{4}(\mathrm{M})$ & 0.021 & 0.030 & 0.048 & 0.028 & 0.054 & 0.065 \\
\hline Cl $(\mu g / m))$ & 385 & 425 & 451 & 497 & 508 & 475 \\
\hline $\operatorname{UOS}(g / L)$ & 84 & 87 & 24 & 12 & 40 & 30 \\
\hline Sp. Gr. & 1.3156 & 1.3187 & 1.3495 & 1.3145 & 1.344 & 1.350 \\
\hline
\end{tabular}




\section{RESULTS}

\subsection{CALCINER OPERATIONS}

Run FiNaS-1 was forced to shut down at a cumulative operating time (COT) of $17.5 \mathrm{~h}$ when acid scrub was inadvertently vented into the off-gas system. The run was started again after modifying the acid scrub tank so that it couldn't pressurize. The run was voluntarily terminated after 39.8 h of operation. Run FINaS-2 was shut down at COT $1.6 \mathrm{~h}$ due to excessive above bed burning caused by the plugging of some holes in the fuel nozzle cap. The run was started again after replacing the cap and was voluntarily terminated after $36 \mathrm{~h}$ of operation. Runs FINas -3 and -4 were both voluntarlly terminated after $39.5 \mathrm{~h}$ of operation. There was continual above bed burning during Run FiNaS-3. After the run, it was found that the above bed burning was caused by plugged holes in the fuel nozzle cap. The fuel nozzle plugging in Runs FINaS-2 and -3 were due to calcine getting into the nozzle cap during startup and not due to flowsheets. Run FINaS-5 was temporarily terminated at COT $7.9 \mathrm{~h}$ due to formation of an ac,glomerate on the fuel nozzle (caused by allowing the calcination temperature to get too low). The bed was sleved, the product collected through COT $7.9 \mathrm{~h}$ plus extra material was added to the sieve bed, and the calciner was restarted and operated without further shutdowns until it was voluntarily terminated at COT $39.99 \mathrm{~h}$. Run FINaS-6 was terminated after $38.95 \mathrm{~h}$ of operation due to a loss of inbedcombustion fire. This loss was caused by the fuel nozzle being coated over.

After Runs FINaS $-1,-2,-3,-4$, and -6 , the inside of the calciner looked relatively good; there was the typical build up on surfaces across from the feed nozzles; other calciner wall surfaces, the distributor plate, propane torch, and thermocouple sheaths were free of agglomerates. Also, in Runs FINaS-1 and -2 , there were small cones on the feed nozzles, while in Run FINaS-6 the fuel nozzle was coated over. The most consistent equipment problem during these runs was that the metal dip-tube in the calciner feed reservoir (connected to the plastic tubing transporting feed from the reservoir to the calciner feed nozzle) plugged frequently. 
During Run FINaS-5 bed temperatures at different heights diverged throughout the run. Apparently bed temperatures diverged when agglomerates formed on the fuel nozzle and came back together again when the agglomerates fell off the nozzle. This theory was supported by the fact that the final bed contained star-shaped agglomerates whose shape indicated that they had formed on the fuel cap. After the run there was: 1) a $1 / 2 i$ ich by 2 inches agglomerate on the wall opposite the feed nozzle (larger than normal), and 2) a small amount of agglomerate covering 2 holes on the top side of the oxygen cap. Otherwise, the inside surfaces of the calciner vessel including walls, nozzles, propane torch, and thermocouple sheathes were free of agglomerates.

The bed particle size growth for Runs FINaS-1, -2, -5, and -6 (Figures 2 and 4 ) was controlled by varying the feed nozzle air ratto (NAR). In Runs FINaS-3 and -4 , the bed particle size continually decreased due to NAR values that were too high (Figure 3). Both runs should probably have used a NAR of about 700 to control bed particle size. NARs used in $10 \mathrm{~cm}$ calciners are higher than those used in larger calciners; NAR ranges of 700 to 1300 are typical in the $10-\mathrm{cm}$ calciner. A NAR of about 1100 is typical for calcining Fluorinel/Sodium Blends without sugar in the $10 . \mathrm{cm}$ calciner.

\subsection{CHARACIERISUICS OF FLUIDIZED-BED AND SOLIDS PRODUCED}

Photos of final bed particles magnified 20 times show that the particles produced in all of the runs were spherical with smooth surfaces. A bed of such particles would give high quality fluidization at the NWCF. These photographs are given in Appendix $D$.

Table 6 gives the important average data obtained on fluidized-bed operation and properties of solids generated during each run; additional information is given in the Appendices.

The low product production rate and low product-to-fines ratio obtained during Runs FINaS $-1,-3,-4$, and -6 indicates that there might be difficulty in bullding bed and maintaining bed height if these flowsheets are used in a large calciner. Run FiNaS-2 had a satisfactory 

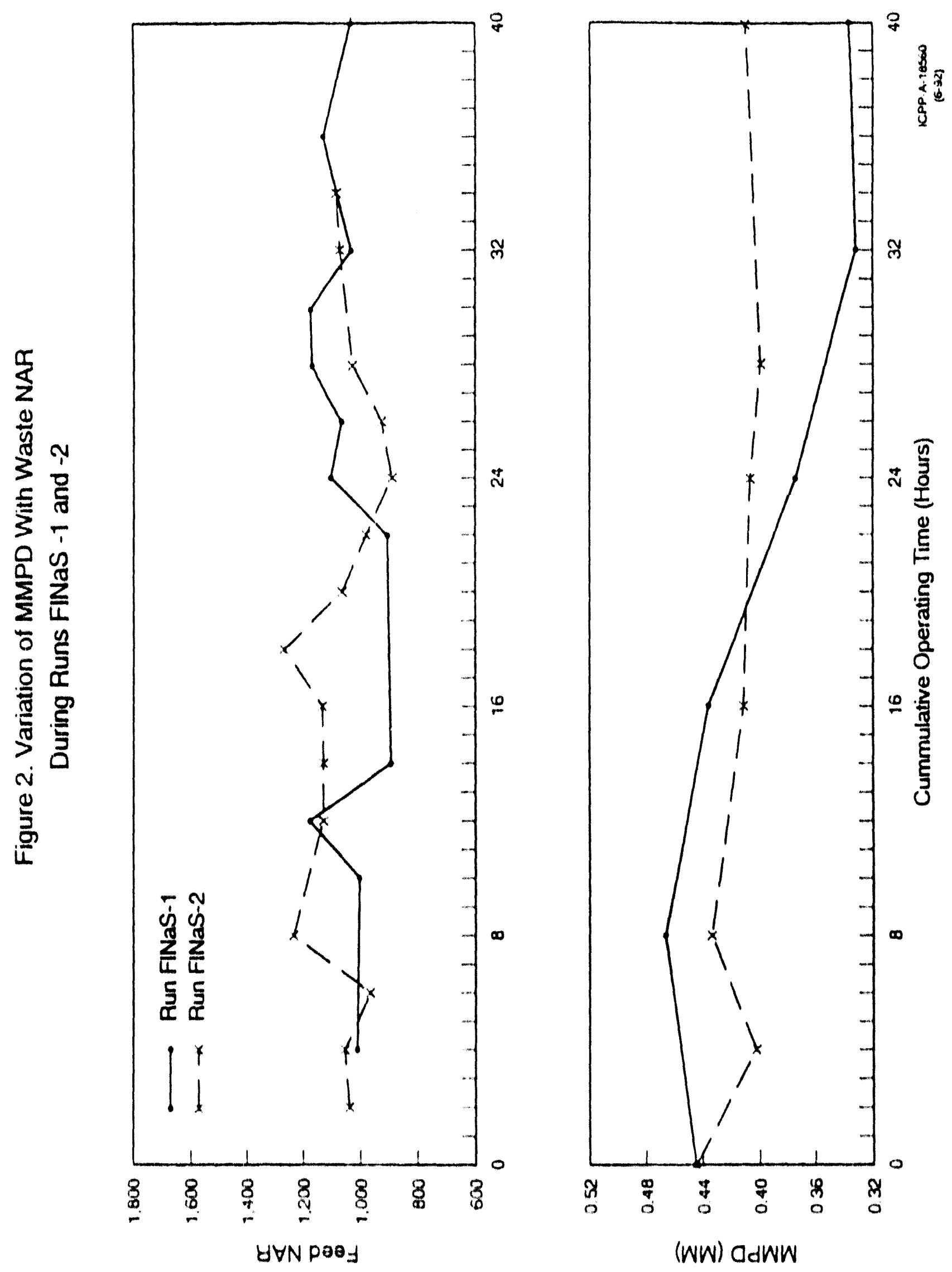

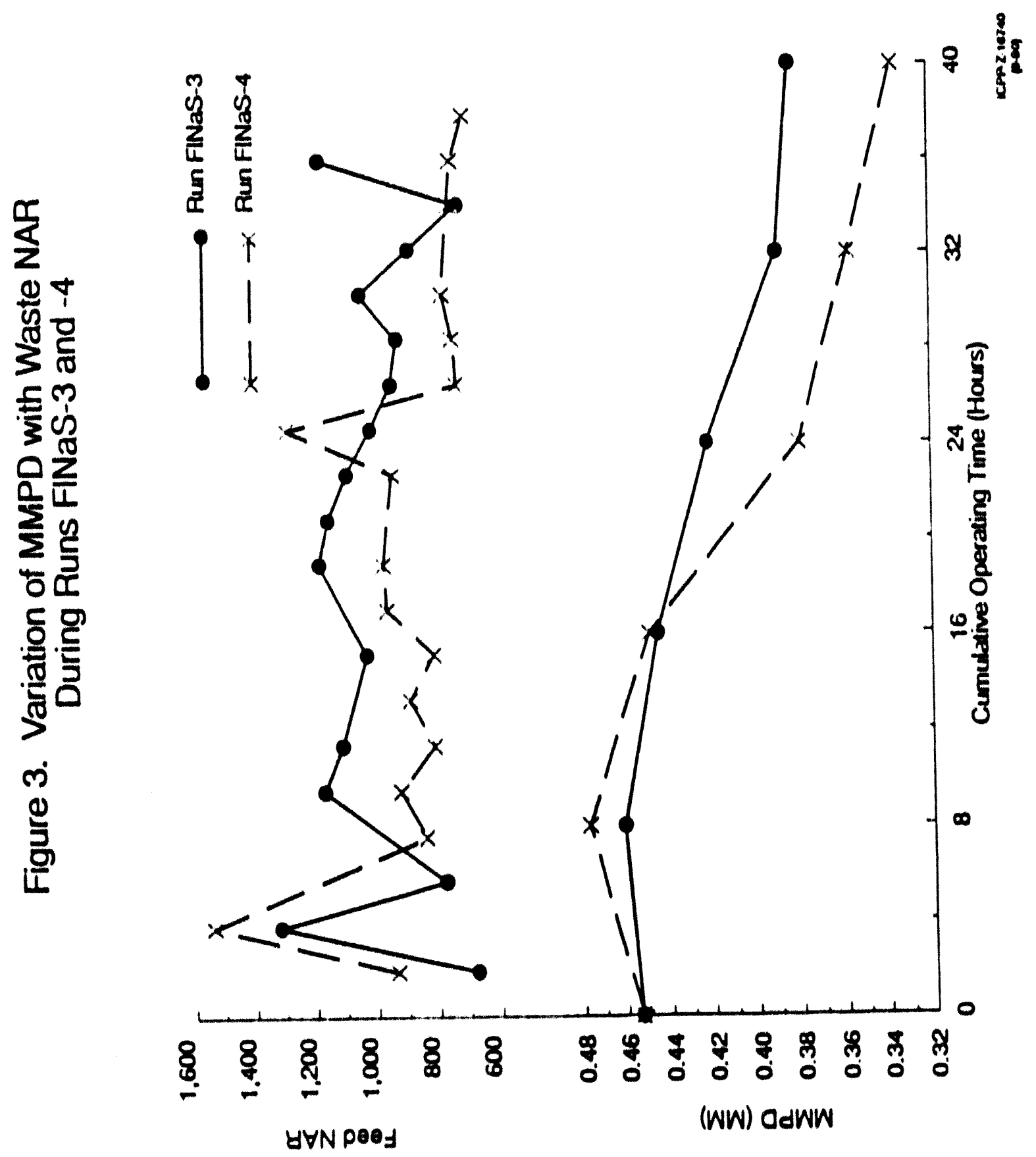


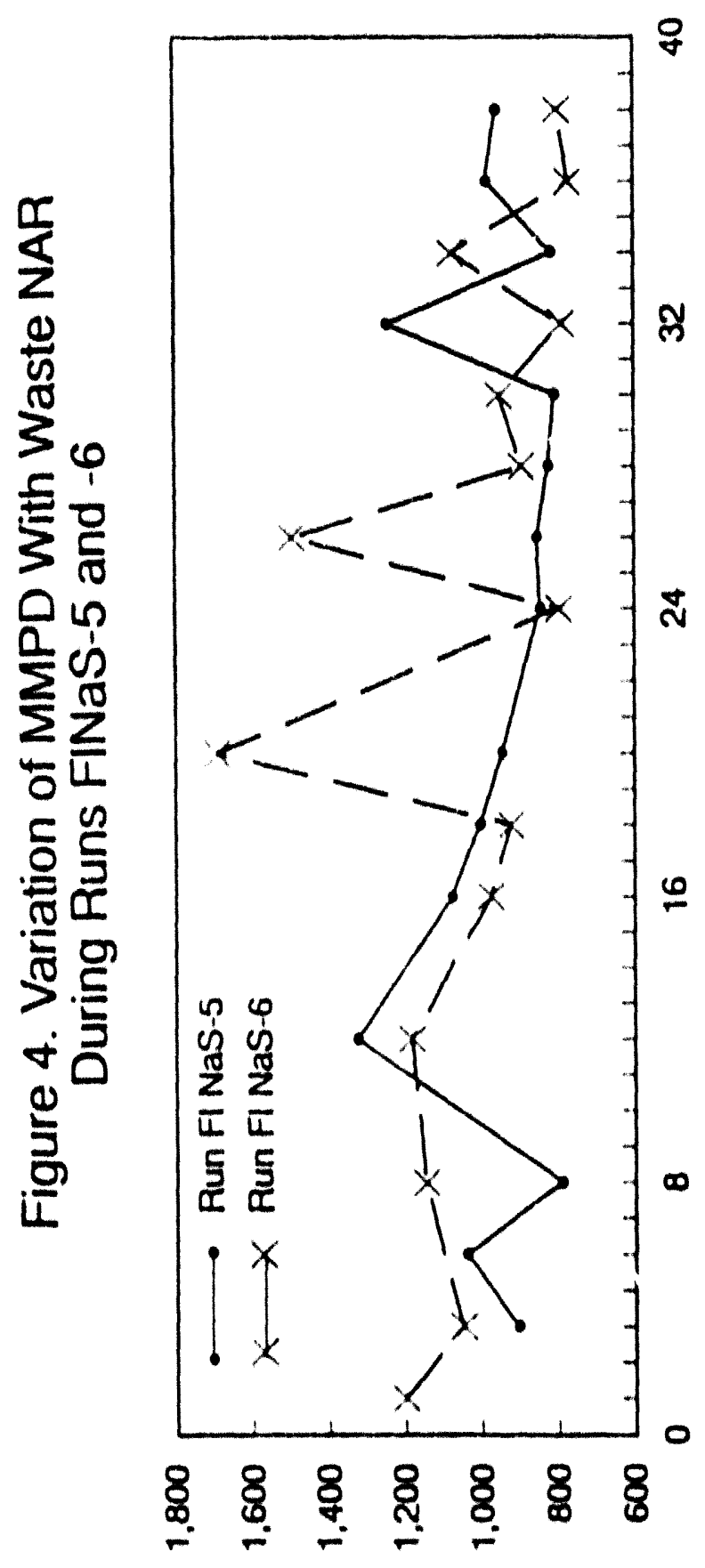

$\forall \forall N$ poog

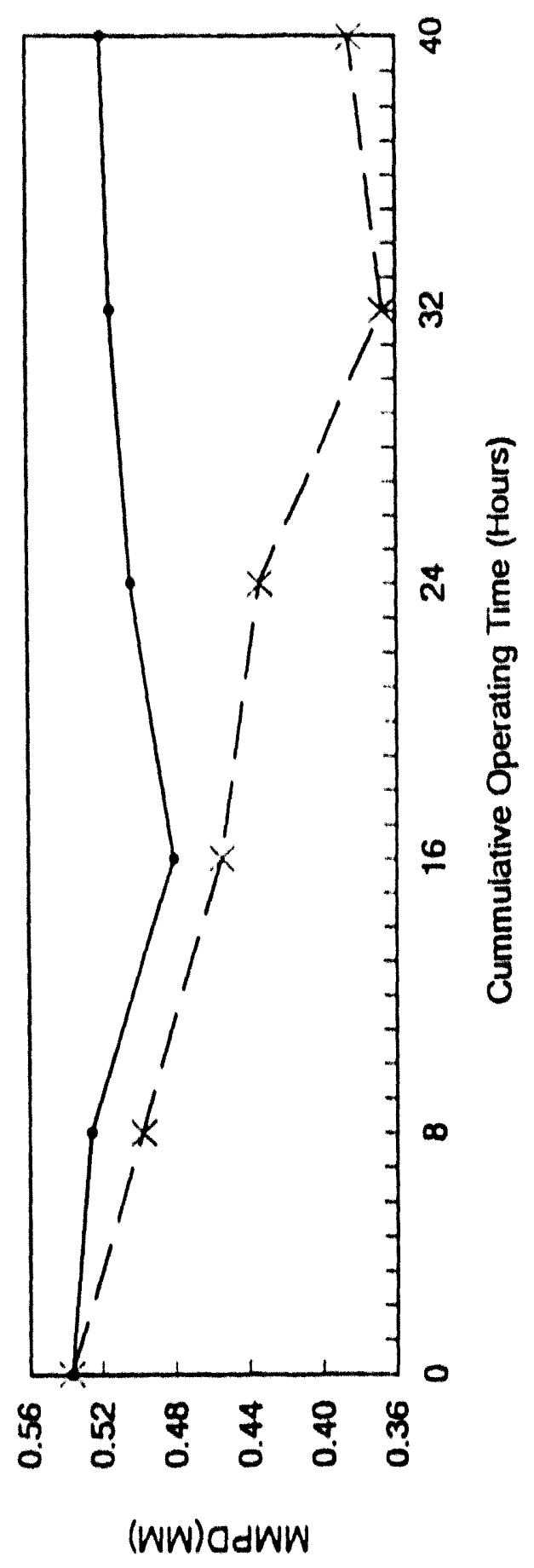




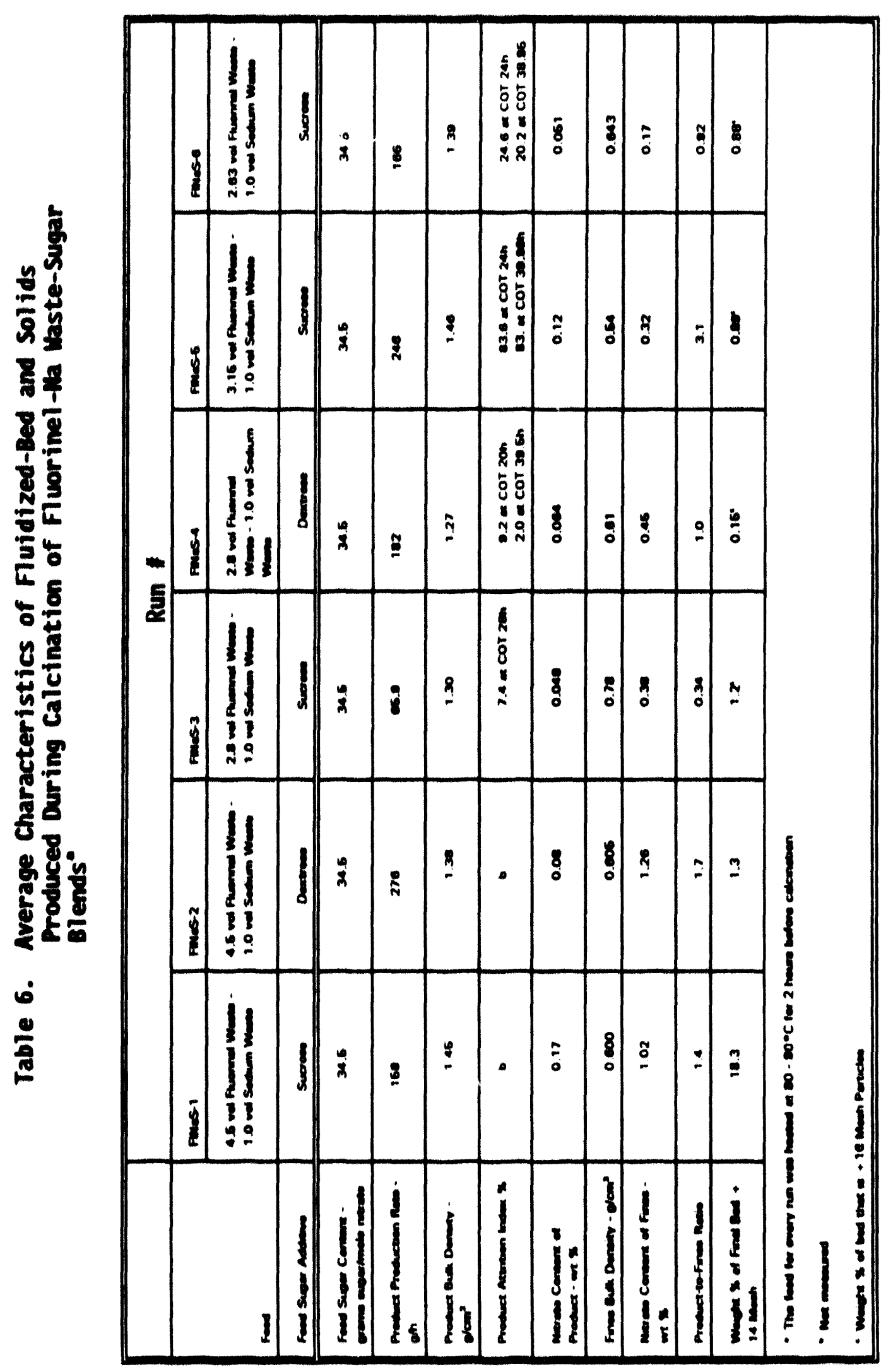


product production rate but a low product-to-fines ratio; thus, if the flowsheet from Run FINaS-2 were used in a large calciner it would be less likely to have problems bullding bed and maintaining bed height. Run FiNaS-5 had a sufficiently high product production rate and product-to-fines ration that maintaining bed height and building bed should not be a problem if this flowsheet is run in a larger calciner.

Runs FINaS-1, $-2,-3$, and -4 had an $A l / N a+K$ mole rat to of 1.0 ; whereas, Runs FINaS-5 and $.6 \mathrm{had} A I / \mathrm{Na}+K$ mole ratios of 0.6 and 1.25 , respectively. The average product-to-fines ratio for runs containing an $\mathrm{Al} / \mathrm{Na}+\mathrm{K}$ mole ratio of 1.0 and 1.25 was 1.0 . The product-to-fines rat 10 for an $\mathrm{Al} / \mathrm{Na}+\mathrm{K}$ mole ratio of 0.6 was 3.1. Thus, the product-to-fines ratio did not change between $A I / \mathrm{Na}+K$ mole ratios of 1.0 and 1.25 , but decreased between mole ratios of 0.60 to 1.0 . These results are exactly opposite of the results seen in previous calciner operations. In previous calciner runs, as the $\mathrm{Al} / \mathrm{Na}+\mathrm{K}$ mole ratio was decreased the amount of fines produced increased. Therefore, the product-to-fines ratio would be expected to decrease (rather than increase as is the case in these tests) as the $A 1 / N a+K$ mole ratio increases. The tests also show that changing the feed's $\mathrm{Al} / \mathrm{Na}+\mathrm{K}$ mole ratio from 0.6 to 1.25 has little or no effect on the bulk and particle densities of the calcine produced.

There was little tendency for bed particles to agglomerate in any of the runs based on the very small welght percent of particles larger than 14 mesh found in the final bed. Run FINaS-I had a large number of particles greater than 14 mesh; however, most of these particles were found on the distributor plate when the calciner was opened after the shut-down at COT $17.5 \mathrm{~h}$. Therefore, there was probably little tendency for bed particle agglomeration during Run FINaS-1.

The sugars in the feeds of all of the runs did an excellent job of destroying nitrates during calcination (residual nitrates in the product and fines from the runs averaged 0.089 and 0.60 wt\%, respectively). In enclosed $30 \mathrm{~cm}$ calciner runs calcining blends of Fluorinel and $\mathrm{Na}$ wastes without sugar, the nitrate content of fines have varied between 6.9 and 11.1 wt\% while the nitrate content of product has varled between 5.7 and $10.3 w t \%$. 
Retrieval tests were performed on homogenous mixtures of product and fines collected during the latter part of Runs FINaS-1, -2, -3, -4, -5, and -6 . The product and fines mixture used for Runs FINaS-1, $-2,-3,-4$, -5 , and -6 was mixed in the same weight ratio as the run's product-to-fines ration shown in Table 6 . The product and fines mixture used for the Run FINaS-3 retrieval test was a product-to-fines weight ratio of 1.0 ; it was assumed that a product-to-fines ratio of 1.0 would have been obtained for Run FINaS-3 if a feed NAR between 700 and 800 had been used. Each retrieval test consisted of attempting (several times) to retrieve a mixture of product and fines that have been subjected to $650^{\circ} \mathrm{C}$ and a pressure of $8.7 \mathrm{psig}$ (the expected worst case conditions in the bin sets) for three days in a sealed can using a vacuum nozzle with vibrator assistance. During retrieval tests a loading rate of $1.5 \mathrm{~kg}$ of calcined solids per $\mathrm{kg}$ of vacuum air is considered satisfactory. The fastest loading rate obtained from six attempts to remove Run FINaS-1 calcined solids from the same can was $2.6 \mathrm{~kg}$ of calcined solids per $\mathrm{kg}$ of air. Run FINaS-1 was very similar to Run FINaS-3 except solids produced had different alkali metal contents. Run FlNaS-1 had an alkali metal content of 5.3 mole \% while Run FINaS-3 had an alkali metal content of 7.5 mole \%. The fastest loading rate obtained from three attempts to remove Run FINaS-3 calcined solids from the same can was $1.4 \mathrm{~kg}$ of calcined solids per $\mathrm{kg}$ of air. Therefore, even with calcined solids of low nitrate content, increasing the alkali metal content of the solids from 5.3 to 7.5 mole \% seems to decrease the loading rate during retrieval.

The fastest loading rate obtained from attempts to remove Run FINaS-2 (alkali metal content of 5.3 mole \%) and Run FINaS-5 (alkali metal content of 7.5 mole \%) calcined solids from their cans were 3.8 and $1.8 \mathrm{~kg}$ of calcined solids per $\mathrm{kg}$ of air, respectively. Cadmium metal crystals plated-out on the interior surface of the can's lid while the mixture from Run FINaS-4 was being subjected to heat; the deposited cadmium metal prevented the system that subjects the calcined solids to pressure from working. Perhaps the cadmium metal deposited on equipment during this retrieval test because different final and/or intermediate products were formed during the reduction of nitrates in the different runs. The fastest loading rate obtained from the attempts to remove Run 
FiNaS-6 calcined solids from the same can was $3.4 \mathrm{~kg}$ of solids per $\mathrm{kg}$ of air. Heating Run FINaS-6 calcined solids at $650^{\circ} \mathrm{C}$ under a pressure of 8.7 psig for three days rusted parts of the stainless steel retrieval equipment that would be in contact with any gases evolved from the calcine. The inside of the retrieval vessel flaked slightly. In addition, it was extremely difficult to remove the retrieval lid from the vessel. The results of the retrieval tests are summarized in Table 7 .

Table 7. Pneumatic Retrieval Rates Using a Vibrator-Assisted Vacuum Nozzle

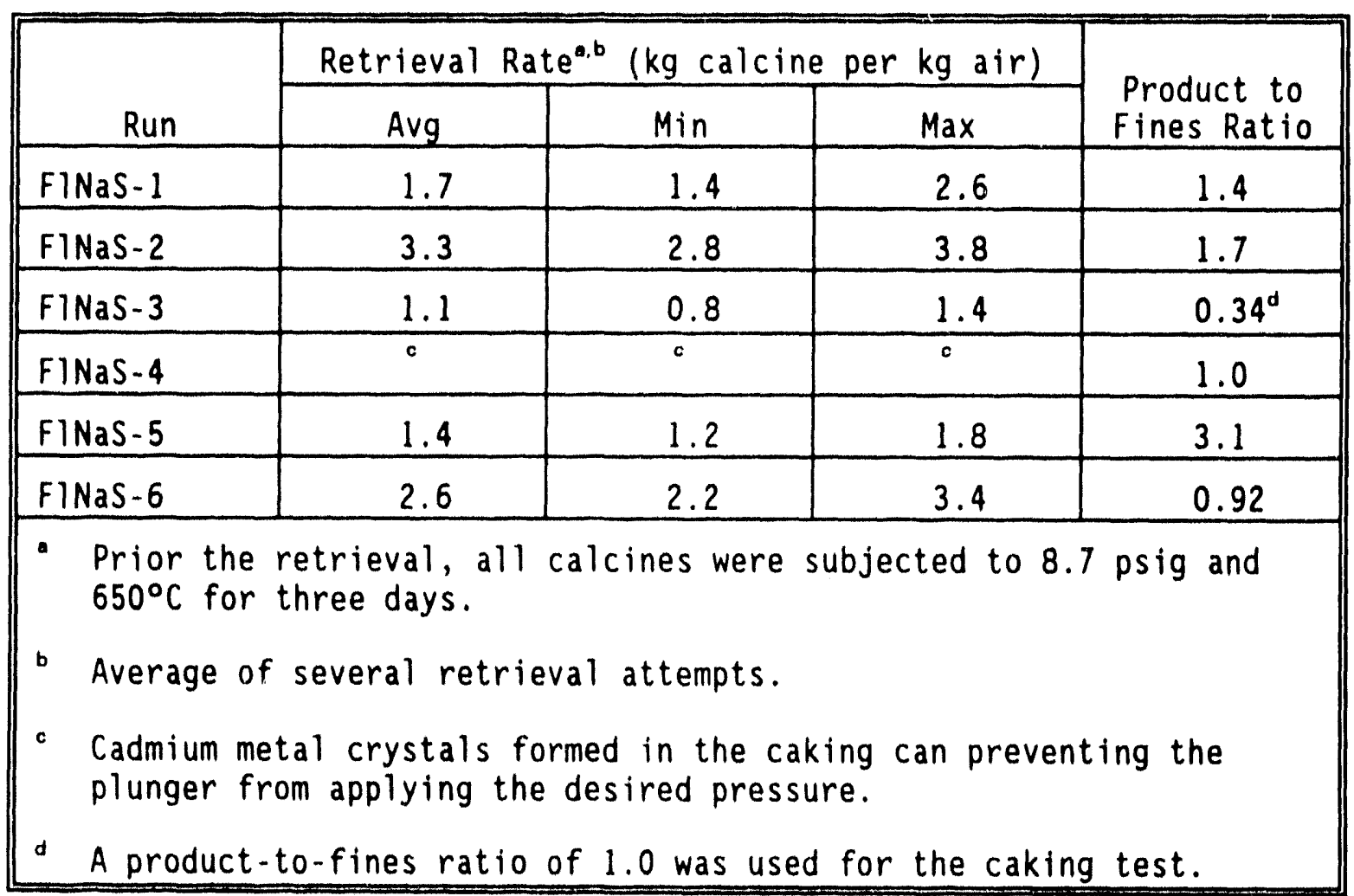

\subsection{BEHAVIOR OF VOLATILES}

Fluoride volatility suppression during all of the runs was excellent. Runs FINaS-5 and -6 had the worst fluoride volatility suppression. During Runs FINaS-5 and $-6,<0.84$ and 0.65 wt\%, respectively, of the fluoride fed to the calciner was lost from the calciner in a form other than $\mathrm{CaF}_{2}\left(\mathrm{CaF}_{2}\right.$ in off-gas is entrained in the fines). In all of the test runs there was always enough boron, zirconium, and aluminum in the off-gas acid scrub solution to complex the 
fluoride sufficiently to prevent excessive corrosion to materials that would be in the NWCF off-gas scrub system. Increasing the Al/ $\mathrm{Na}+\mathrm{K}$ mole ratio from 0.60 to 1.25 had no effect on fluoride behavior.

Values summarizing the behavior of chloride in calciner off-gas during the runs are given in Table 8 . Chloride retention in calcined solids was excellent, averaging 91 wt\% of the chloride found in calciner streams in Run FINaS-1, 93 wt\% in Run FiNaS-2, 92 wt\% in Run FiNaS-3, $>97$ wt\% in Run FINaS-4, 93.8 wt\% in Run FINaS-5, and 95.9 in Run FINaS-6. Increasing the $\mathrm{Al} / \mathrm{Na}+\mathrm{K}$ ratio from 0.60 to 1.25 had no effect on chloride behavior.

In all of the runs the product, fines, acid scrub, caustic scrub, and condensate were analyzed for organic and inorganic carbon. Organic carbon getting by the acid scrub system would either go through the off-gas caustic scrubber system (for analyses) or through the condensers. From the information obtained from Runs FINaS-1 and -2 , there was no way to determine how much unburned organic carbon was released from the calciner into the off-gas system. By the time the acid scrub was analyzed for organic carbon much of the initial organic carbon in the acid could have been converted to carbonate, and organic carbon could have gotten by the caustic scrubber or condenser since neither system should be effective for collecting organic carbon. Because of the continual above bed burning experienced during Run FINaS-3, the concentration of organic carbon in Run FiNaS-3 calciner streams was unrealistically low. Inorganic carbon values for Run FINaS-3 should also be suspect because of the above bed burning. Table 9 summarizes carbon behavior during all of the runs except Run FINaS-3 which was omitted for the above mentioned reasons. In calculating percent of total carbon in calcined solids, acid scrub, and caustic scrub; the total is the sum of the carbon in those three media. In calculating percent of total carbon found in condensate; the total is the sum of the carbon concentrations found in the calcined solids, acid scrub, and condensate instead of caustic scrub. In Runs FiNaS-1, -3, -5 , and -6 , sucrose was used as an additive and the wt\% of total carbon fed to the calciner in these runs found in calciner streams as organic (unburned and/or not converted to inorganic carbon) carbon was $7.2,1.5,1.3$, and 1.5 respectively. ${ }^{6}$ In 


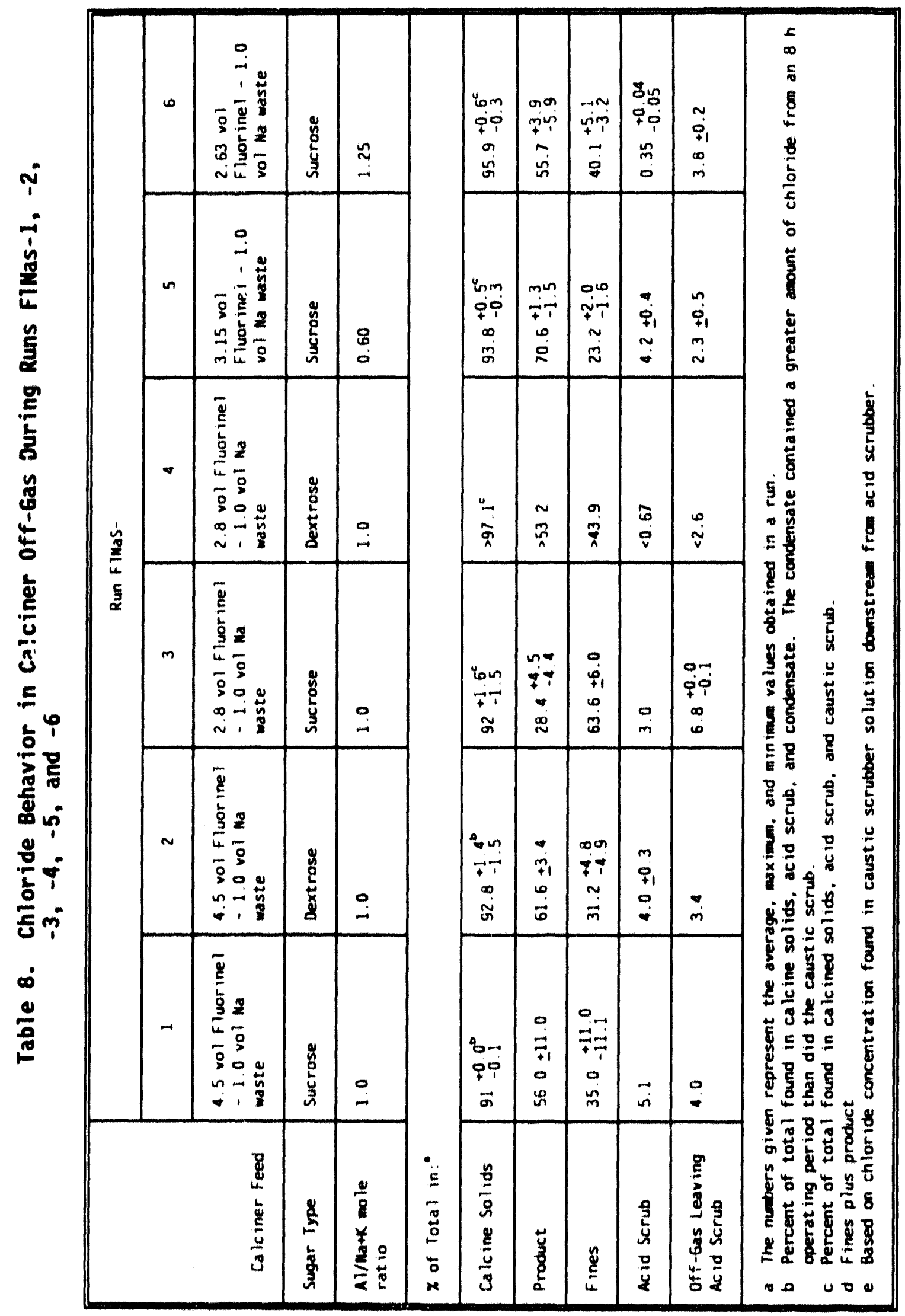




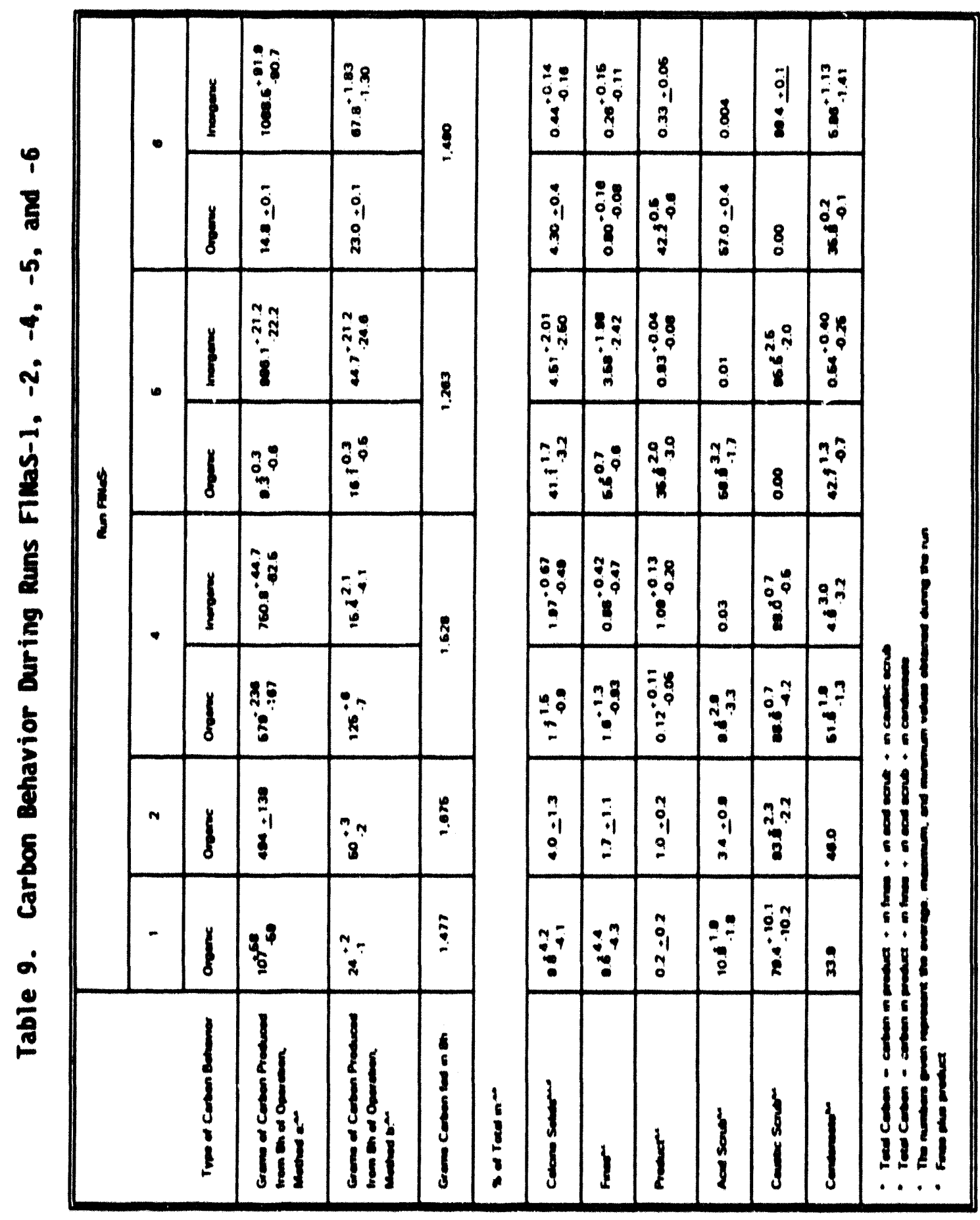


Runs FINaS-2 and -4, dextrose was used as an additive and the wt\% of total carbon fed to the calciner in these runs found in calciner streams as organic carbon was 29.5 and 38 , respectively. ${ }^{\circ}$ In the NWCF, either 29.5 or 38 wt\% of the carbon (in the form of sugar) fed to the calciner escaping the off-gas acid scrubber as unburned carbon would probably plug filters and silica gel beds. Thus, increasing the alkall metal content of calcine solids produced from 5.3 to 7.5 mole $\%$ doesn't change the amount of unburned carbon created during calcination of the blends.

Therefore, in runs calcining blends of fluorinel and $\mathrm{Na}$ wastes containing sugar as an additive: a) sucrose burns and/or is converted into inorganic carbon compounds more completely than is dextrose, and b) the low value for wty of total carbon fed to the calciner found in calciner streams as organic carbon in Run FINaS-3 was not caused by above bed burning but by the fact that sucrose rather than dextrose was used." The carbon behavior experlenced during Runs FINaS-5 and -6 are similar. Thus, changing the Al/ $\mathrm{Na}+\mathrm{K}$ mole ratio from 0.60 to 1.25 had no effect on carbon behavtor.

During Run FINaS-5, 3.4 wt\% of the cadmium fed to the calciner was lost from the calciner. During Run FINaS-6, 3.6 wt\% of the cadmium fed was carried over. Most of the cadmium in the off-gas system was probably carried out of the calciner vessel in the fines.

\subsection{MLSCELLANEOUS CALCINAIION CHEMISTRY}

$X$-ray diffraction examination of the final beds from Runs FINaS-3 and -4 gave the same results: a) principal crystalline constituents were $\mathrm{CaF}_{2}, \mathrm{ZrO}_{2}$, and $\mathrm{Ca}_{0}{ }_{16} 2 \mathrm{r}_{1.08} \mathrm{O}_{105} ;$ and b) possible minor crystalline constituents were $\mathrm{NaCl}, \mathrm{CdO}$, and an unidentifiable constituent. The presence of $\mathrm{NaCl}$ as a minor constituent could explain the excellent chloride retention seen in these runs. The sugar's destruction of nitrates could have left the $\mathrm{Na}^{+}$lons free to bind with the $\mathrm{Cl}$ lons; thereby, retaining the chloride in the calcine. This examination gave no clue as to why cadmium metal plated-out on equipment during retrieval studies on Run FINaS-4 solids. 
There seemed to be more difficulty keeping feed solids in suspension during runs FiNaS-3 and -4 than in previous runs using sugar in the feed. Some of these sollds from Run FINaS- 3 were examined by $x$-ray diffraction and emisston spectroscopy. The results of the $x$-ray diffraction examination showed ammonium citrate to be the principal crystalline constituent and an unidentified, crystalline, minor constituent to be present also. Emission spectroscopic examination of these solids showed 2 irconium and calclum to be major constituents ( $25 \mathrm{wt} \%$ ); and aluminum, boron, iron, and magnes fum to be minor constituents ( 21 to $<5 \mathrm{wt} x$ ).

Run FINaS-4 off-gas was sampled for its carbon monoxide-carbon dioxide ratio (a measure of combustion efficiency) during the run at cumulative operatling times of 19 and 21 hours via a sample bomb installed on the caustic scrubber inlet. Combustion efficiency for these two samples averaged 90\%. Two additional samples were taken at the end of the run after operating on nitric acid fuel for approximately 0.5 hours. Combustion efficiency for these two samples averaged 85\%. Results of the off-gas samples are listed in Table 10.

Table 10. Carbon Monoxide in Off-gas During 10-cm Calciner Run Fimas-4

\begin{tabular}{|c|c|c|c|c|c|c|}
\hline Sample & $\begin{array}{c}c 0 \\
(v 0 \mid x) \\
\end{array}$ & $\begin{array}{l}\mathrm{CO}_{2} \\
(\mathrm{vo} \mid \mathrm{x}) \\
\end{array}$ & $\begin{array}{l}\mathrm{CH}_{6} \\
(\mathrm{~N} O \mathrm{ix})\end{array}$ & 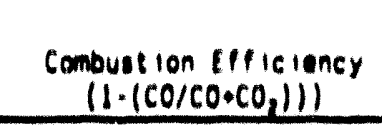 & $\begin{array}{l}\text { Foodrcle } \\
\text { (LPH) }\end{array}$ & $\begin{array}{l}\text { 0,/fuel } \\
\text { Ralio } \\
\text { (si/l) }\end{array}$ \\
\hline $\cot 19$ & 11 & 113 & 0.031 & A6. 9 & 21 & 2230 \\
\hline $\cot 21$ & 0.08 & 11. & 0.002 & 931 & 28 & 2280 \\
\hline Aclelfiend $=A$ & 1.0 & 0.30 & $0.050^{\circ}$ & 060 & 2.0 & 2010 \\
\hline Ac ldf ceed - 6 & 1.0 & 1.2 & 0.049 & 82.3 & 2.0 & 2040 \\
\hline
\end{tabular}

The final bed and agglomerates produced in Runs fINaS.5 were examined by $x$-ray diffraction and by emission spectroscopy. $x$-ray diffraction showed: a) $\mathrm{CaF}_{2}$ and $\mathrm{C}_{\mathrm{C}_{0}}{ }_{10} 2 \mathrm{r}_{0}{ }_{20} \mathrm{O}_{1}$ ar to be major constituents of both agglomerates and non-agglomerated particles; b) $\mathrm{CA}_{2} \mathrm{~A}, \mathrm{O}_{0} \mathrm{~F}$ to be a major const/tuent of agglomerates and a minor const /tuent of non-agglomerated particles; c) Cazro, to be a minor constituent of agglomerates; and d) $\mathrm{Ca}_{3} 2 \mathrm{rSi}_{2} \mathrm{O}_{3}, \mathrm{CdO}, 2 \mathrm{rSiO}_{4}$, and $\mathrm{NaCl}$ to be possible 
minors of non-agglomerated particles. Emisston spectroscopy showed agglomerates contained: $C d, A$, and $C a$ as major constituents ( 25 wt\%), and $\mathrm{Na}, \mathrm{Zr}, \mathrm{Cr}, \mathrm{Mg}$, and $\mathrm{Fe}$ as minor constltuents $(21$ to $<5 \mathrm{wt} \%)$. The spectrochemical examination for non-agglomerated particles was the same as for agglomerates except Iron was not present.

The final product produced during Run fiNaS- 6 was examined by $x$-ray diffraction and emission spectroscopy. The $x$-ray diffraction examination showed that: $\mathrm{CaF}_{2}$ and $\mathrm{C}_{\mathrm{a}_{0}}{ }_{2} 2 \mathrm{r}_{0}{ }_{00} \mathrm{O}_{1}$ es were major crystalline constituents, and $\mathrm{CdO}$ and $\mathrm{NaCl}$ were possible minor crystalline constltuents. $X$-ray diffraction did not find $\mathrm{C}_{2}, 2 \mathrm{rS} \mathrm{S}_{2} \mathrm{O}_{2}, \mathrm{C}_{2}, \mathrm{Al}_{3}, \mathrm{O}_{0} \mathrm{~F}$, and $2 \mathrm{rS} / \mathrm{O}_{4}$ in the final product produced from Run FiNas. 6 as it did in the final product from Run Finas-5. The emission spectroscopy examination of Run FiNaS-6 final product showed: $2 r, C d, A l$, and $C a$ as major constituents; and $\mathrm{Mg}, \mathrm{Cr}$, and $\mathrm{Na}$ as minor constituents. This spectrochemical examination is similar to that obtained on Run finas.5 final product except $2 r$ is a major constituent of Run FINaS.6 final product and a minor constituent of Run fiNas.s final product. 


\section{CONCLUSIONS AND RECOMMENDATIONS}

\subsection{CONCLUSLONS}

The following conclusions were reached based on results presented in this report.

A. Sucrose and dextrose were both effective at destroying nitrate in the feed solutions. The amount of nitrate reduction in feed solutions ranged from 33 mole $x$ to 53 mole $\%$, with 45 mole $*$ being the average amount of nitrate reduced.

B. Sucrose is a more desirable nitrate reductant than dextrose because the unreacted sucrose is consumed in the calciner to a greater extent than the unreacted dextrose. Therafore, using sucrose as a feed additive would probably prevent the NWCF slllca gel beds from plugging.

C. Runs finas-3, $4,-5$, and -6 successfully produced calcined solids with a Natk mole $x$ of 7.5 .

D. Product-to.fines ratlos were low for all runs except for Run FINas.5.

C. As the Al/Na+K mole ratio increased the product-to-fines ratto decreased. This unexpected result cannot, at this time, be explained.

F. None of the calcine produced, except Runs FINaS-2 and -6, had a favorable retrlevabllity.

G. Very few $10 . \mathrm{cm}$ Calciner Pllot Plant operational difficulties occurred with the sucrose or dextrose flowsheets. 


\subsection{BECOMMENDALIONS}

The following recommendations were reached based on information presented in this report:

A. Further testing should be conducted on catalysts that could shorten the induction period of the sugar reactions. Laboratory studies have shown that the inttlation perlod required for sucrose reaction with nitrates during feed make up and the amount of sucrose required for efficient reduction of nitrate during calcination can be reduced by using vanadium pentoxide or forric nitrate as additives".

B. An evaluation of the NO, emissions due to the destruction of nitrates by sugars should be conducted to determine if NO, abatement will be capable of handling the large releases (an average of 45 mole $x$ reduction of nitrates) of NO, produced by the sugar reaction.

C. The amount of sugar that must be added to the foed to start a deflagration under typlcal calciner operating conditions (temperature and pressure) should be determined before calcining blends of fluorinel and sodium wastes containing sucrose in the NUCF.

D. Llquid or granulated sugar should be used to prevent sugar dust explosions. 


\section{LIIERATURE CITED}

1. B. J. Newby, Gelaination of Sodium Bearine Haste Using Aluminum Mitrite. WINCO-1026.

2. EGSG Idaho, Inc., Lab Notebook U608, assigned to B. J. Newby; Pp. $14.83(10.7 .82)$.

3. P. A. Anderson, PAA-15-87, to J. R. Berreth, "Calculated Chemical Composition of Current and Future High Level Wastes, "dated July 15, 1987.

4. R. I. Donovan, Mestinghouse Idaho Nuclear Co., Inc., personal comunication (October 1986).

3. EGAG Idaho, Inc., Lab Notebook U608, assigned to B. J. Newby; PD. 96 $(10.7 .82)$.

6. WINCO Notebook In-348, assigned to H. B. Eldredge, PD. 33.57 (6-12-89). 


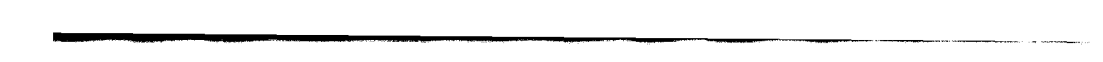

\section{APPENDIX A}

RUNS FINaS.I and -2 
Cemmon operating conditions

Acid Scrub Recycle to Feed: None

Startup Bed: Calcined Zr/Wa Waste blend

Faed Nozele: Spraying system Co 40100 Llquid. 120 Alr

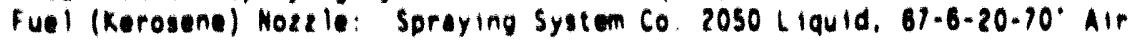

\section{Common Feed Characteristics}

Giend Ratio: 4.5 vol Fluorinel Waste/l vol ha Waste

Ca/f nole Ratio: 0.7

Feed Sugar Cone.: 34.5 g suger/Mole of $\mathrm{NO}_{3}$

Al/Natk mole Ratlo: 1.0

Hatk mole $x$ in Cale ined solide: 3.3

Run No.

FINaS-1

FINaS-2

Feed Sugar Additive

\section{Specific Bun Conditions*}

Calcination temperature. 'C

$503 \pm 8$

$50 r^{+10}$

Waste Feed Rate-l/h

$2.1+0.8$

$2.5 \pm 0.06$

Pluldizing Air Rete-L/e

$0.85 \div 0.12$

$-0.18$

$0.18 \cdot 0.08$

Plutdizing velocity loo low nosele) -m/s

$0.27 \div 0.05$

$0.25 \div 0.03$

Feed Atomizing Alr Noce le Pressure-psio

$20 \pm 2$

$21^{+5}$

Feed Atomizing Alr Rate-L/s

$0.63+0.02$

$+0.02$

Fuel Mozzle $O_{2}$ Rate-L/s

$0.35 \pm 0.05$

$0.40 \div 0.05$

Kerosene feed Rate-l/h

$0.10+0.12$

$0.72+0.04$

Guel Mozzle $0_{2} /$ fuel Ratio

$2095+424$

$2040+206$

MAR

$1129+604$
-230

$1087+214$

Bed Iurnover-x

83.4

95.0

Run Durnelonch

39.8

36

- The nubers given represent the average, maximun, and minimun valuas obtained during - given run. 
Table A-2 Characteristics of Flutdized-Bed and Sollds Produced

During Runs FINaS-1 and - 2

\section{Common Faed Characteristics}

Blend Ratio: 1.5 vol fluorinel Waste/l vol Na vaste

Calf mole Ratio: 0.7

leed Sugar Cone.: 34.5 g Suger/mo le of $\mathrm{MO}_{3}$

Al/Na+k mole Ratio: 1.0

Na+k mole $x$ in Calcined Solids: 5.3

Seecific Propertlels of Fluidized Bed and Produced Solids*

Run No

Foed Sugar Additive

\section{Product:}

Production Rate $(g / h)$

Bulk Density $\left(\mathrm{g} / \mathrm{cm}^{3}\right)$

MMPO $(\mathrm{mm})$

Particle Denaily $\left(\mathrm{g} / \mathrm{cm}^{3}\right)$

Nitrate Content (wt $x)$

\section{Eines:}

Production Rate $(g / h)$

Bulk Dens lty of inal fines collected $\left(g / \mathrm{cm}^{3}\right)$

Nitrate Content (wtx)

Product-to-fines Rat 10

\section{Starting Bed:}

MMPO $(\mathrm{mm})$

Bulk Density $\left(0 / \mathrm{cm}^{3}\right)$

Attirtion Indax of $-30+10$ Mesh Fraction $(x)$

\section{Einal Bed:}

\section{$\operatorname{MMPO}(\mathrm{mm})$}

Bulk Density $\left(\mathrm{g} / \mathrm{cm}^{3}\right)$

Attrition Indax of $-30+10$ Mash Fraction $(x)$

Ut $X$ of Bad that is +14 Mesh Particles

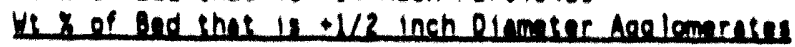

finas - I

Sucrose

Finas-?

Oaxtrose

159

218

$145 \cdot 0.23$

1.38 .0 .11

0.3824 .0 .0498

$0.4107=0.0249$

$2.20 \pm 0.05$

$2.00 \div 0.05$

$0.17+0.02$

$0.08 \stackrel{+0.02}{0.03}$

$\begin{array}{ll}115 & 162 \\ 0.600 & 0.805 \\ 1.02 .0 .19 & 1.28 .0 \\ 1.1 & 1.7 \\ & \\ 0.1423 & 0.4423 \\ 1.54 & 1.54 \\ 11 & 71\end{array}$

- The nubers given reprasens the overage, maximum, and minimum values obteined during - given run. 
APPENDIX B

RUNS FINaS-3 and -4 


\section{Common Operating Conditions}

Acid Scrub Recycle to Feed: None

Startup Bed: Calcined $\mathrm{Zr} / \mathrm{Na}$ Waste Blend

Feed Nozzle: Spraying System Co. 40100 Liquid, $120 \mathrm{Air}$

Fuel (Kerosene) Nozzle: Spraying System Co. 2050 Liquid, 67-6-20-70 Air

\section{Common Feed Characteristics}

Blend Ratio: 2.8 vol fluorinel Waste/1 vol Na Waste

$\mathrm{Ca} / \mathrm{F}$ mole Ratio: 0.70

Feed Sugar Conc.: $34.5 \mathrm{~g} \mathrm{Sugar} / \mathrm{Mole}$ of $\mathrm{NO}_{3}$

A1/Na+K mole Ratio: 1.0

NatK mole $X$ in Calcined Solids: 7.5

Run No.

Feed Sugar Additive

Specific Run Conditions*

Calcination Temperature- ' $C$

Waste Feed Rate-L/h

Fluidizing Air Rate-L/s

Fluidizing Velocity (below nozzle) $-\mathrm{m} / \mathrm{s}$

Feed Atomizing Air Nozzle Pressure-psig

Feed Atomizing Air Rate-L/s

Fuel Nozzle Atomizing $\mathrm{O}_{2}$ Rate-L/s

Kerosene Feed Rate-L/h

Fuel Nozzle $\mathrm{O}_{2} /$ Fuel Ratio

NAR

Bed Turnover-x

Run Duration-h
FINaS-3

Sucrose

$503+17$

$-12$

$1.8 \pm 0.5$

$\begin{array}{cc}0.72+0.06 & -0.07\end{array}$

$0.23+0.03$

$18.2+11.8$

$0.57+0.30$

$-0.12$

$0.53+0.02$

$-0.06$

$0.70+0.04$
-0.03

$2494+609$
-488

$1196 \pm 277$

$90.7^{* *}$

39.5
FINaS-4

Dextrose

* The numbers given represent the average, maximum, and minimum values.

** Used product plus fines to calculate bed turnover rather than product only. 
Table B-2 Characteristics of Fluidized-Bed and Solids Produced During Runs FINaS-3 and -4

Common Feed Characteristics

Blend Rat 10: 2.8 vol Fluorinel Waste/l vol Na Waste

$\mathrm{Ca} / \mathrm{F}$ mole Ratio: 0.10

Feed Sugar Conc.: $34.5 \mathrm{~g}$ Sugar/Mole of $\mathrm{NO}_{3}$

Al/Na+K mole Ratio: 1.0

NatK mole \% in Calcined Solids: 7.5

Specific Properties of Fluidized Bed and Produced Solids*

Run No.

Feed Sugar Additive

FINAS-3

Sucrose

FINaS-4

Dextrose

\section{Product:}

Production Rate $(g / h)$

65.9

182

Bulk Density $\left(\mathrm{g} / \mathrm{cm}^{3}\right)$

$\begin{array}{cc}1.30 & +0.02 \\ -0.03 & \end{array}$

$1.27 \pm 0.03$

MMPO $(m))^{*}$

Particle Density $\left(\mathrm{g} / \mathrm{cm}^{3}\right)$

$0.4200+0.0407$
-0.0367

$2.02+0.04$

$0.3999+0.0175$

Attrition Index of $-40+50$ Mesh Fraction (\%)

$-0.03$

$2.01+0.06$

Nitrate Content (wt\%)

7.4 at $\cot 28 \mathrm{~h}$

9.2 at $\operatorname{COT}$

$0.049 \pm 0.002$

20h: 2.0 at

COT $39.5 \mathrm{~h}$

$0.064 \pm 0.09$

\section{Fines:}

Production Rate $(\mathrm{g} / \mathrm{h})$

192

181

Bulk Density $\left(\mathrm{g} / \mathrm{cm}^{3}\right)$

Nitrate Content (wt\%)

$0.78+0.10$

$0.61+0.05$

$0.38+0.15$

$0.45+0.19$

Product-to-Fines Ratio

0.34

1.0

\section{Starting Bed:}

MMPD (mm)

Bulk Density $\left(\mathrm{g} / \mathrm{cm}^{3}\right)$

Attrition Index of $-30+40$ Mesh Fraction (\%)

$\begin{array}{ll}0.4544 & 0.4544 \\ 1.47 & 1.47 \\ 71 & 71\end{array}$

\section{Final Bed:}

MMPO (mm)

Bulk Density $\left(\mathrm{g} / \mathrm{cm}^{3}\right)$

Attrition Index of $-30+40$ Mesh Fraction ( $y$ )

Wt $X$ of Bed that is +14 Mesh Particies

Wt $\%$ of Bed that is $+1 / 2$ inch Dlameter Agalomerates

0.3218
1.36
16.2
1.2
0.30

0.15

0.30

0.00

* The numbers given represent the average, maximum, and minimum values obtained during a given run. 


\section{APPENDIX C}

RUNS FINaS-5 and -6 
Table C-1 Operating Conditions for Runs FINaS-5 and -6

\section{Common Operating Condittons}

Ac la Serub Recyc le to feed:

Startup Bed:

Foed Nozzla:

Fuel (kerosene) Nozzle:

Common Feed Conditions
None

Calcined Zr/ho Waste olend

Spraying syotems Co. 10100 llquid, 120 alr

Spraying Systems Co. 67-6-20-10 olr

1.5

0.10

34.5 sugar/mole of $\mathrm{NO}_{3}$

Sucrose 
Table C-2 Operating Conditions for Runs FINaS-5 and 6 (continued)

\section{Specifte Condtitons}

\begin{tabular}{|c|c|c|}
\hline Run no & I Imas.s & PInas 6 \\
\hline Blend Rotlo - Vol fl Vastervol he Waste & $3.15 / 10$ & $2.63 / 1.0$ \\
\hline fuel Notzle liquid (Spraying systems to.) & 1650 & 2050 \\
\hline Al/matk mole notio & 0.00 & 1.25 \\
\hline Coleination temperature. 'C & $498+11$ & $498 \pm 1$ \\
\hline Yaste foed Rate $\cdot$ l/h & $209 \div 0.13$ & $2.13 \div 0.91$ \\
\hline Fluidizing Alr Rate * L/S & $015 \div 0.05$ & $0.10 \stackrel{0.02}{0.00}$ \\
\hline Flulaling velocity (below nozile) $\mathrm{m} / \mathrm{s}$ & $\begin{array}{l}0.23 \quad 0.03 \\
=0.02\end{array}$ & $0.25+0.01$ \\
\hline Foed Atomizing Air Nose le Prosesure - psio & $161+2.6$ & $10.5+2.5$ \\
\hline Foed Atomizing Ale Mate $\cdot 1 / \mathrm{s}$ & $0.66 \cdot 0.04$ & 0.02 .0 .00 \\
\hline Foed Houle Atomleing 0 , hate " $1 / 6$ & $0.30: 0.05$ & $0.38 \div 0.00$ \\
\hline fuel notile 0,2 fuel Ratio & $2319 \begin{array}{r}.546 \\
\end{array}$ & $2280+169$ \\
\hline Kurovene beed $A$ at: $=6 / n$ & $039 \div 0.07$ & $0.60 \cdot 0.03$ \\
\hline mak & $1000 \stackrel{+419}{209}$ & $1040+638$ \\
\hline Bed lurnover : $x$ & 912 & 021 \\
\hline Run Ouration $=n$ & 1999 & 36.95 \\
\hline
\end{tabular}


Table C.3 Characteristlcs of Fluldized-Bed and Sollds Produced During Runs FiNaS.5 and -6

\section{Eend chereterdetics}

Bland Ratio (Vol fl Waste/Vol Na Waste):

Ca/f Mole Rat lo:

Feed Sugar Concentration:

Al/Ma+K Mole Ratlo:

MatK Molex in Calcine Solids:

Feed Sugar Additive:
3.15/1.0 for Run FINaS.5;

$2.63 / 1.0$ for Run FINas.6

0.10

$34.5 \mathrm{~g}$ of sugar/mole of $\mathrm{NO}$,

0.60 for Run FINas.5;

1.25 for Run FiNas.6

7.3

Sucrose 
lable C 4 Chardeteristics of 11 widized Bed and solids Produced During Runs fllas 5 and 6 (continued)

Broperties of Elutdiced bed and eroduced sulids

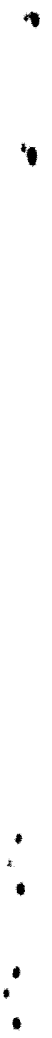

\begin{tabular}{|c|c|c|}
\hline Aun Mo & 11 as 5 & rimas \\
\hline \multicolumn{3}{|l|}{ noduet } \\
\hline Droduct on ate $(a n)$ & 46 & 156 \\
\hline 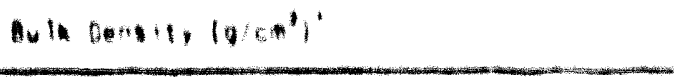 & 163.64 & $\begin{array}{c}191.062 \\
0.101 \\
\end{array}$ \\
\hline $\operatorname{man}(\mathrm{mm})^{\circ}$ & 501 00111 & 01118.00104 \\
\hline 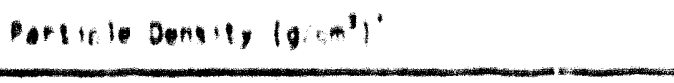 & 12000 & 211.004 \\
\hline Allition indes of 10.50 mesh 1 tation $|x|$ & 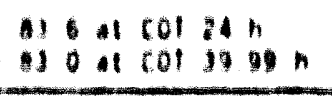 & 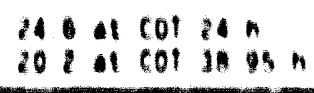 \\
\hline 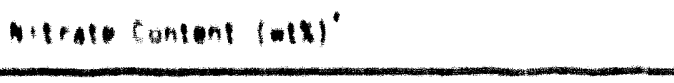 & 011.011 & 0041.9029 \\
\hline doanic conan tantenthet & 9510 & 010 \\
\hline \multicolumn{3}{|l|}{ Nhos } \\
\hline 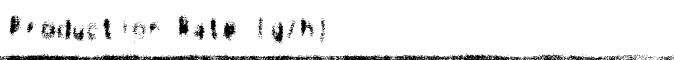 & 1 & 111 \\
\hline 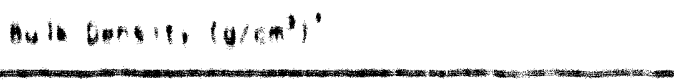 & $4.10 .1 \%$ & 064.0011 \\
\hline Wille comtont $\mid$ ant & $\begin{array}{lll}11.015 \\
\end{array}$ & 011.0011 \\
\hline 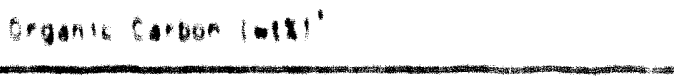 & 0 - 1601 & 042006 \\
\hline 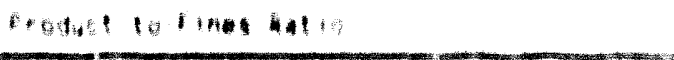 & 11 & 09 \\
\hline \multicolumn{3}{|l|}{ Exating sod } \\
\hline movitim & +14 & 0.14 \\
\hline W.6.6.1, 11:1 & 14 & 190 \\
\hline 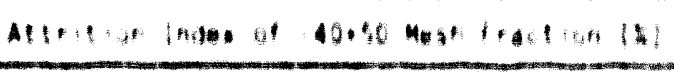 & 1 & 1 \\
\hline \multicolumn{3}{|l|}{ Nind 204} \\
\hline $\operatorname{mat}(\min )$ & 01076 & 01413 \\
\hline Butr Denolly $\left(g / \mathrm{cm}^{3}\right)$ & 14 & 1320 \\
\hline At111100 16000 10.50 most boction 15 & 41 & 4 \\
\hline 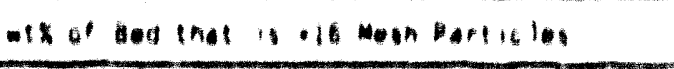 & 0 & 0 \\
\hline 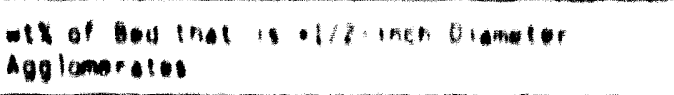 & 64 & $0 m$ \\
\hline
\end{tabular}


APPENOIX 0

20x Magniffection Photographs of

find Bed Calcine Particles

4 
Table D.1

20X Magnification Photographs of Final Bed

Calcine Particles

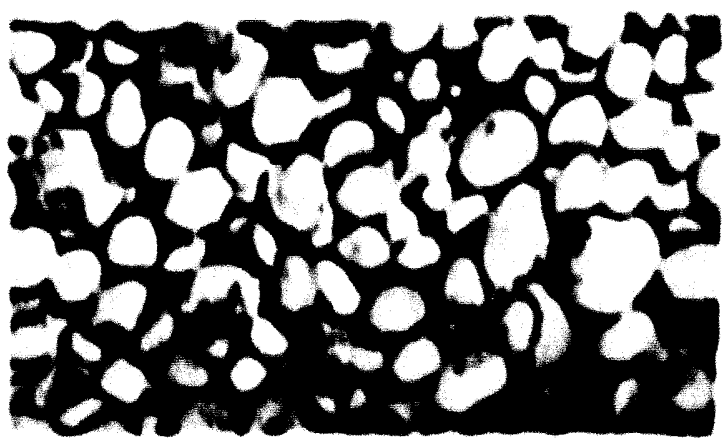

Aun Fwas 1

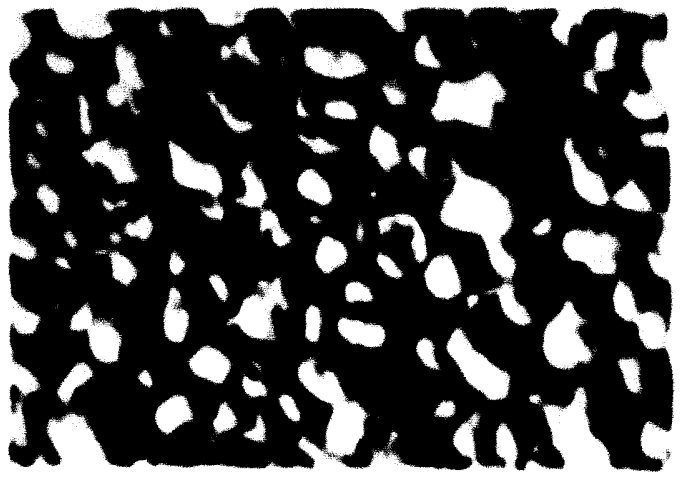

Aun F INas a

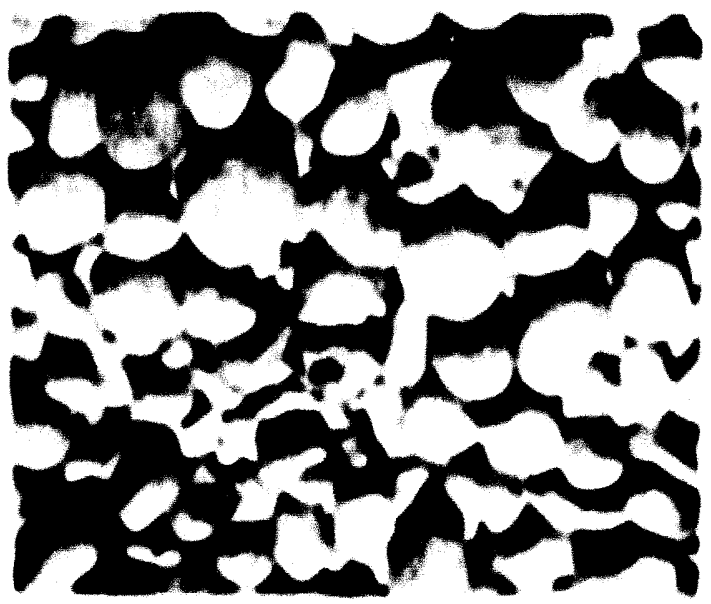

Hunfinas

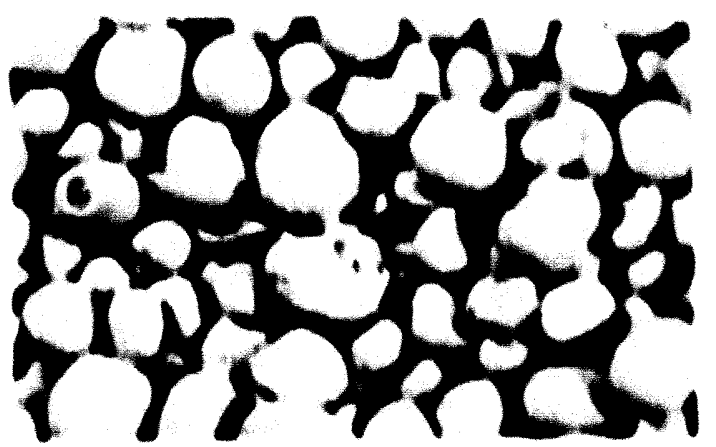

Aun Fnas 2

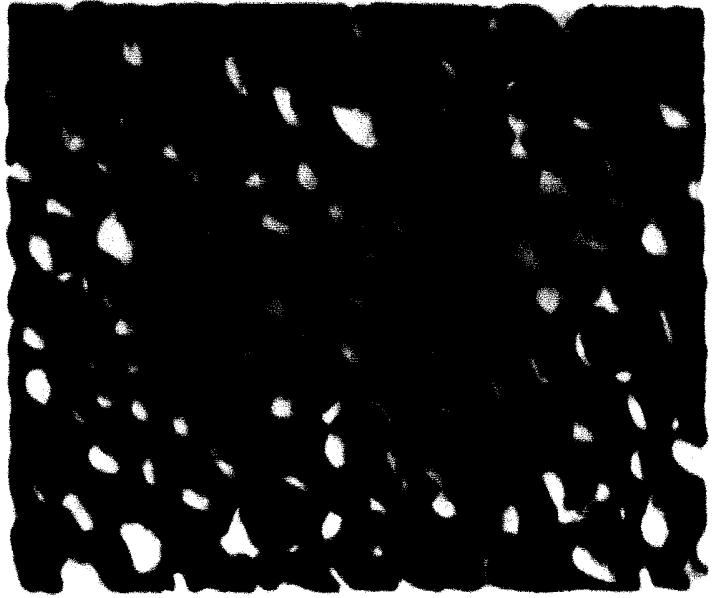

Aun FiNag 4

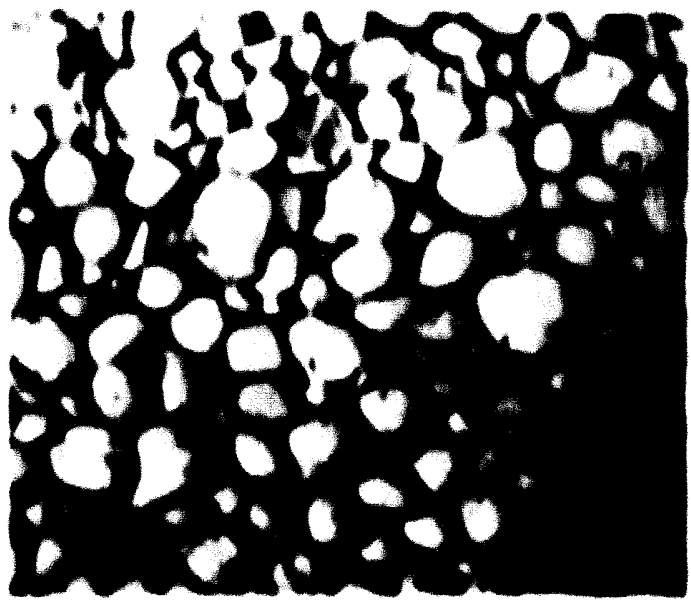

Aun Finas is 

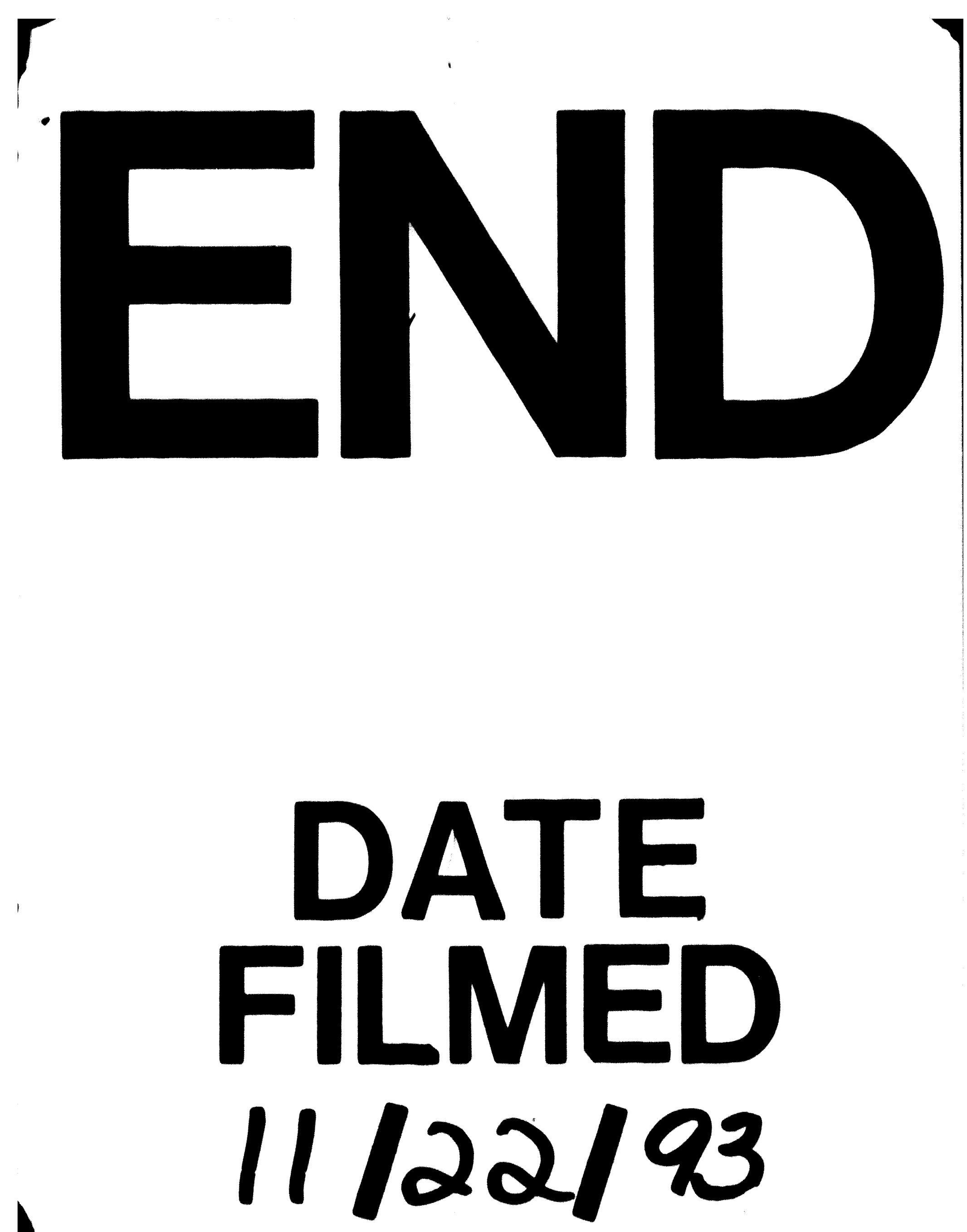
